\title{
Marine modification of terrestrial influences on Gulf hypoxia: Part II
}

\author{
E.C. Krug and K. Merrifield \\ Illinois State Water Survey, 2204 Griffith Drive, Champaign, IL, USA 61820 \\ Email for corresponding author: ekrug@sws.uiuc.edu
}

\begin{abstract}
This study examines potential marine modification of two classes of terrestrial influence on Gulf hypoxia: (1) the flow of nutrient-rich water from the Mississippi/Atchafalaya River Basin and (2) the massive physical, hydrological, chemical and biological change associated with the Atchafalaya's partial capture of the Mississippi River. The latter involves repartitioning of a total flow of about $20000 \mathrm{~m}^{3} \mathrm{sec}^{-1}$, equal to that of 13 Nile Rivers, and a sediment load of 210 million metric tonnes $\mathrm{yr}^{-1}$,nearly 20 times that delivered by all of the rivers of the East Coast of the USA. Also involved is the loss of hundreds-to-thousands of years of stored nutrients and organic matter to the Gulf from enormous coastal wetland loss. This study found that the oceanography of the Gulf minimises the impact of both classes of terrestrial influence from the Mississippi River and its nearby estuaries on Gulf hypoxia. Oceanographic conditions give events associated with the Atchafalaya River a disproportionately large influence on Gulf hypoxia. A truly holistic environmental approach which includes the full effects of this highly dynamic coastal area is recommended to better understand and control Gulf hypoxia.
\end{abstract}

Keywords: Gulf of Mexico, hypoxia, nutrients, geology, oceanography, cabbeling, boundary current, Mississippi Trough; dissolved oxygen

\section{Introduction}

This contribution builds upon a companion study (Krug, 2007) by applying a Gulf of Mexico perspective to the hypoxic zone; in relation to how the Gulf processes inputs from the Mississippi/Atchafalaya River Basin (MARB) and coastal change, and the extent of the northern Gulf of Mexico's interaction with coastal change. In doing so, the assumptions used to define the Gulf hypoxia problem are examined further. To expand understanding of the causes and controls of Gulf hypoxia beyond MARB inputs and coastal change, an oceanographic perspective is applied to examine potential marine controls of terrestrial influences on Gulf hypoxia. The roles of oceanic, Gulf-wide and local currents, and their interactions with and within the hypoxic zone and with terrestrial inputs of water, nutrients and sediment, are examined using published literature, studies, compilations of data and satellite imagery.

\section{Background}

The National Science and Technology Council's Committee on Environment and Natural Resources (CENR) and others identify input of nutrient-rich water from the Mississippi/ Atchafalaya River Basin (MARB) as the prime cause and means of control of hypoxia in the northern Gulf of Mexico (Turner and Rabalais, 1991; Rabalais et al., 1999; CENR, 2000). Gulf hypoxia forms during warmer months when a warmer and less saline surface water layer develops, enabling organic matter decay to deplete dissolved oxygen (DO) in underlying water to $\leq 2 \mathrm{mg} \mathrm{O} \mathrm{L}^{-1}$. Such hypoxic bottom water $\mathrm{DO}$ values have been occurring in continental shelf waters between the Mississippi River to at least the Texas border (Fig. 1). Hypoxia is lethal to many species of desirable aquatic and marine organisms (Rabalais et al., 1999), although nutrient inputs can also enhance fishery production in adjacent coastal waters (Diaz and Solow, 1999). 
The annual occurrence of an apparently regional seasonal hypoxia in the northern Gulf of Mexico was noticed by environmental monitoring and research programmes starting with the 1973 flood of the Mississippi and Atchafalaya rivers (Fucik, 1974; Ragan et al., 1978; Bender et al., 1979; Oetking et al., 1979a,b; Bedinger et al., 1981; Harper et al., 1981; Gaston, 1985; Rossignol-Strick, 1985; Pokryfki and Randall, 1987). Since 1985, the US government has supported a Gulf hypoxia monitoring programme; its officially-reported size is that measured during the programme's mid-summer cruise. In response to the doubling of the average extent of Gulf hypoxia starting with the 1993 flood, a Watershed Nutrient Task Force was formed to solve the Gulf hypoxia problem (Mississippi River/Gulf of Mexico Watershed Nutrient Task Force, 1997; 2001; Krug, 2007).

The following assumptions have been used to predict the effects of the MARB on Gulf hypoxia. Oxygen-consuming organic loading is from net algal productivity, the amount of which is dependent upon nitrogen (N) from the MARB (Turner and Rabalais, 1991; Doering et al., 1999; Goolsby et al., 1999; Rabalais et al., 1999). Although inputs of atmospheric and oceanic $\mathrm{N}$ are acknowledged, the response of net primary productivity has been calculated to be directly proportional to $\mathrm{N}$ loading and $\mathrm{N}$ loading from the MARB. The $\mathrm{N}$ in all of the flow of the Atchafalaya River and 53 percent of the flow of the Mississippi River supports this algal growth (Turner and Rabalais, 1991; Rabalais et al., 1999 , p. 35). Using the assumed MARB N loading and the $290 \mathrm{~g} \mathrm{C} \mathrm{m}^{-2} \mathrm{yr}^{-1}$ productivity figure that Sklar and Turner (1981) determined for water just offshore of the Barataria Bay estuary as the net primary productivity for $106866 \mathrm{~km}^{2}$ of the entire Louisiana/Texas continental shelf water west of the Mississippi, Turner and Rabalais (1991) estimated that $\mathrm{N}$ recycles about four times per year to support algal growth. This $\mathrm{N}$ recycling estimate has been retained (Rabalais et al., 1999, p. 87) even though the $290 \mathrm{~g} \mathrm{C} \mathrm{m}^{-2}$ $\mathrm{yr}^{-1}$ estimate is no longer considered representative (Rabalais et al., 1999, p. 62) - $122 \mathrm{~g} \mathrm{C} \mathrm{m}^{-2} \mathrm{yr}^{-1}$ has come to be used for the eastern part of the hypoxic zone off the Mississippi River (Justic et al., 1997; Rabalais et al., 1999, pp. 81-85).

Subsequently, the Watershed Nutrient Task Force developed the Action Plan for Reducing, Mitigating, and Controlling Hypoxia in the Northern Gulf of Mexico. The Action Plan calls for a 30 percent reduction in MARB nitrogen $(\mathrm{N})$ discharge to the Gulf to reduce the aerial extent of Gulf hypoxia from the then most recent 5-year running average of $\sim 14000 \mathrm{~km}^{2}$ to a 5-year running average of less than $5000 \mathrm{~km}^{2}$ by 2015 (Mississippi River/Gulf of Mexico Watershed Nutrient Task Force, 2001). The Watershed Nutrient Task Force recognizes that significant uncertainties remain and there is need to reduce these to improve management options. Thus, room for improvement is planned with reassessment and the development of a new Action Plan every five years (Mississippi River/Gulf of Mexico Watershed Nutrient Task Force, 2001); however, the deadline has since dropped back to December 2007.

Since the 2001 Action Plan there has been increased emphasis added to MARB phosphorus (P) as a nutrient of concern in controlling Gulf hypoxia (e.g. Justic et al., 2003a,b, 2005; USEPA, 2004) and also a recognition that the northern Gulf of Mexico itself has become inherently more sensitive to hypoxia formation (Stow et al., 2005). A history of the above institutional focus on the causes and control of Gulf hypoxia is provided by Krug (2007) who noted that during the time within which Gulf hypoxia has been observed to develop there has been essentially no overall increase in MARB inputs of water, N, and P (Turner and Rabalais, 1991; Rabalais et al., 1999; Goolsby et al., 1999; CENR, 2000: Kelly et al., 2001; Krug, 2007). But there has been another kind of change. The Gulf environment in which Gulf hypoxia is contained is undergoing massive physical, hydrological, chemical and biological change associated with the Atchafalaya's partial capture of the Mississippi River involving a total flow of about $20000 \mathrm{~m}^{3}$ $\mathrm{sec}^{-1}$ (Goolsby et al., 1999, p. 2) which is equal to that of 13 Nile Rivers (Wright and Coleman, 1973; Ludwig et al., 1996) and a sediment load of 210 million metric tonnes $\mathrm{yr}^{-1}$, nearly 20 times that delivered by all of the rivers of the East Coast of the USA (Curtis et al., 1973). As detailed in the companion study (Krug, 2007), this type of immense riverswitching, delta-building event occurs here about once a millennium. Such coastal environmental change, which includes repartitioning of MARB inputs, is capable of inducing even persistent anoxia, year-round total loss DO, and has done so prior to European settlement of the MARB. This study adopts an oceanographic perspective to examine potential marine controls of terrestrial influences on Gulf hypoxia.

\section{Results and discussion}

\section{BOUNDARY CURRENT EFFECTS}

\section{Marine and MARB Nitrogen}

The northern Gulf of Mexico has a Boundary Current flowing along its margins which strongly interacts with the hypoxic zone (Figs. 1 and 2). Such boundary currents occur along the margins of marine basins throughout the world. In the northern hemisphere the Earth's rotation deflects currents clockwise, these currents being naturally strongest in the west and weakest in the east (Greenspan, 1962; 


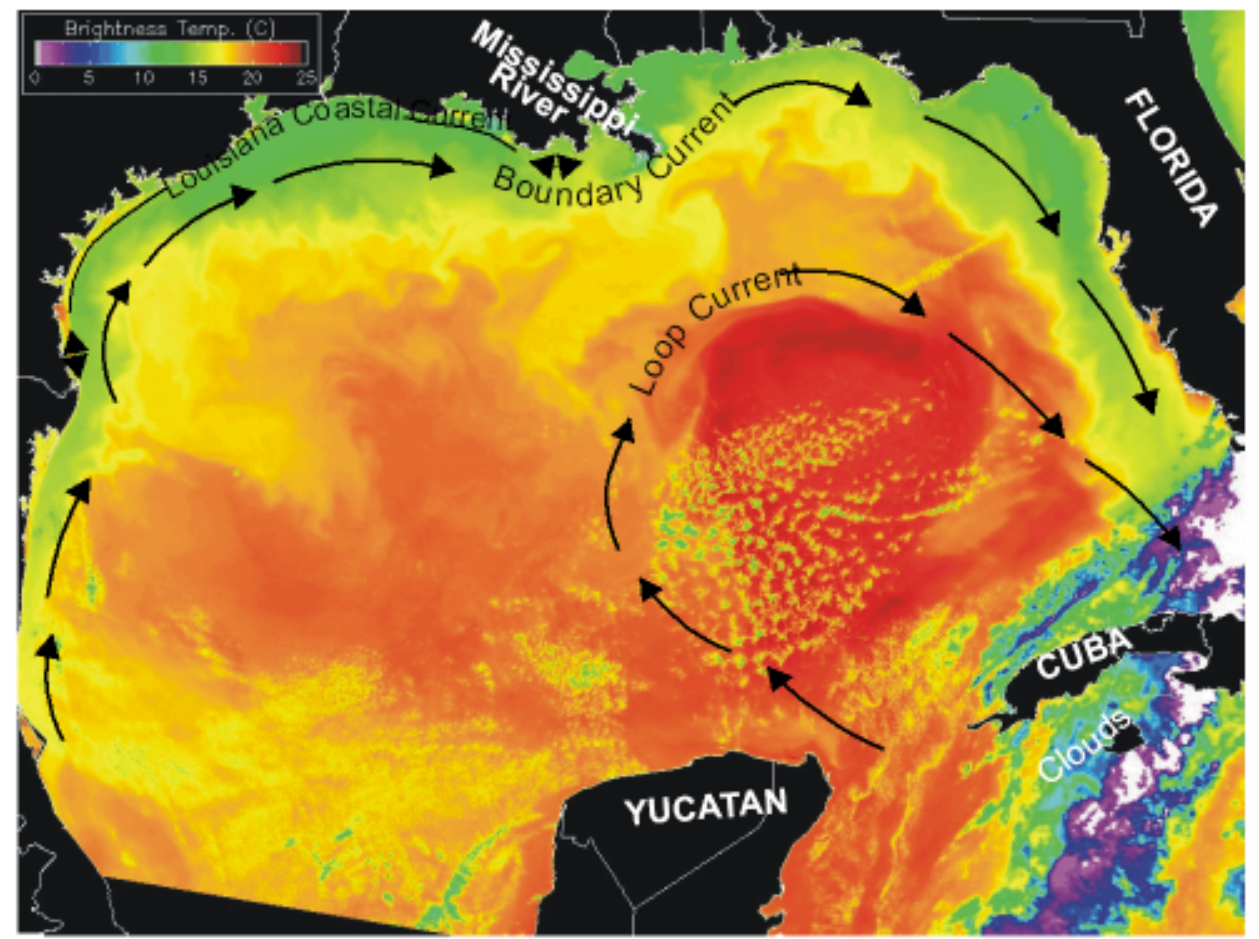

Fig. 1. Sea surfae temperature image of the Gulf of Mexico Loop and Boundary currents. See figure description in the Appendix.

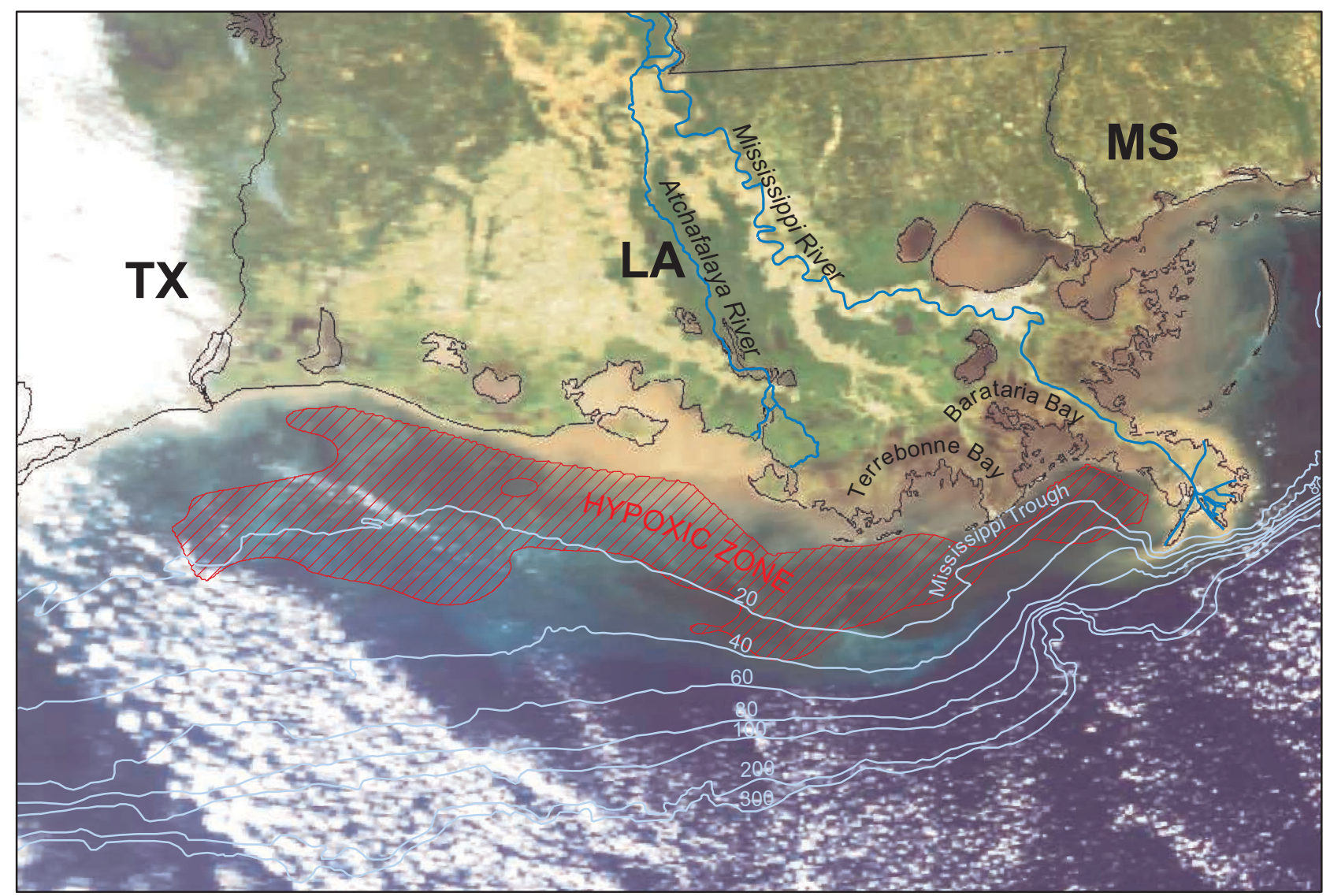

Fig.2. The measured extent of hypoxia in 2002 (Louisia Universities Marine Consortium, 2000) in the northern Gulf of Mexico (Space Science and Engineering Center, 2002). Contour depths are in metres. See figure description in the Appendix. 
Pickard, 1979). For example, a boundary current exists in the North Atlantic Ocean and the Gulf of Mexico's Loop Current (Fig. 1) is a branch of the North Atlantic Ocean's Western Boundary Current. It enters the Gulf of Mexico by flowing north past the Yucatan, turning clockwise within the Gulf, and extends eastward through the Florida Strait between Florida and Cuba. The Loop Current reinforces the Gulf's Boundary Current (Fig. 1), annually cycling 230 million metric tons $\mathrm{NO}_{3}-\mathrm{N}$ through the Gulf of Mexico (Blaha and Sturges, 1978). The MARB supplies an average of 1.6 million metric tons $\mathrm{N} \mathrm{yr}^{-1}$ to the Gulf (CENR, 2000). Generally, this nutrient-bearing Loop Current water maintains a higher salinity, forming a vertical salinity gradient (pycnocline). The Gulf-wide pycnocline is taken to be $200 \mathrm{~m}$; pycnocline depths of less than $200 \mathrm{~m}$ indicate net upwelling, $>200 \mathrm{~m}$ net downwelling. The pycnocline is $159 \mathrm{~m}$ for the Louisiana shelf and rises at times to above $19 \mathrm{~m}$ around the mouth of the Mississippi River (Blaha and Sturges, 1978). For example, Govoni and Grimes (1992) measured the upwelling of nutrient-containing high salinity water $\left(>36 \mathrm{~g} \mathrm{~kg}^{-1}\right)$ to less than $8 \mathrm{~m}$ depth just off the mouth of the Southwest Pass — the main source of Mississippi River water to the hypoxic zone.

There is an appreciable N flux through the Gulf's surface layer above the pycnocline; this flux is estimated to be about 120 million metric tons $\mathrm{NO}_{3}-\mathrm{N} \mathrm{yr}^{-1}$. It is estimated that $\mathrm{N}$ upwelled from the deep layer below the pycnocline contributes 25 percent of biologically-utilised $\mathrm{N}$ in the top $10 \mathrm{~m}$ of the Louisiana shelf water (Walsh et al., 1989) and later study found that only 40 percent of $\mathrm{N}$ in water of the continental shelf here is from terrestrial sources of all origins (Lopez-Veneroni, 1998). Whereas MARB $\mathrm{N}$ is used in calculating net primary productivity and a recycling rate of $\mathrm{N}$ in the $106866 \mathrm{~km}^{2}$ of continental shelf water west of the Mississippi to the Mexican border, the presence of appreciable marine $\mathrm{N}$ points for the need to include marine $\mathrm{N}$ in calculations involving Gulf hypoxia. Indeed, the following factors indicate that the Walsh et al. (1989) estimate of marine $\mathrm{N}$ contribution is underestimated. Their upwelling estimate assumes the Loop Current is the circulation driver of the Gulf. However, the Gulf's Western Boundary Current is stronger than that induced by the Loop Current. The Gulf of Mexico has a latitudinal range large enough to set up its own Western Boundary Current (McLellan, 1965; Huang and Goodell, 1970; Sturges and Blaha, 1976; Pickard, 1979, pp. 134-158; Cho et al., 1998; Wiseman and Sturges, 1998). Indeed, even estuaries the size of Chesapeake Bay are reported to have such circulation (e.g. Fischer et al., 1979, p. 237). The Gulf's latitudinallydriven Western Boundary Current is strengthened by the Loop Current as well as by the prevailing winds of the
Bermuda High, the latter making the Gulf's Western Boundary Current strongest in summer. It also results in the reversal of the western flow of the Louisiana Coastal Current - the thin band of coloured water inshore of the hypoxic zone in Fig. 2 and too small to be seen on the scale of the Loop and Western Boundary Currents in Fig. 1 - to the east (Kutkuhn, 1963; Blaha and Sturges, 1978; Temple and Martin, 1979; Bedinger et al., 1981; Crout and Hamiter, 1981; Halper et al., 1988; Dowgiallo, 1994; Martinez-Lopez and Pares-Sierra, 1998; Wang et al., 1998; Vidal et al., 1999; Chen et al., 2000; Ohlmann et al., 2001; Welsh and Inoue, 2002; Lee and Mellor, 2003; Zavala-Hidalgo et al., 2003).

This year-round Western Boundary Current induces yearround bottom Ekman upwelling that draws in nutrientbearing water onto the Texas and Louisiana continental shelf and transports this upwelled water eastward toward the Mississippi River delta. This current also pulls in nutrientbearing water from the cyclonic and anticyclonic deeperwater gyres off the Louisiana/Texas coast (Bogdanov, 1965; Muller-Karger et al., 1991; Walsh, 1991; Sahl et al., 1993, 1997; Sturges, 1993; Oey, 1995; Biggs et al., 1996; Martinez-Lopez and Pares-Sierra, 1998; Chen et al., 2000; Sturges and Leben, 2000; Ohlmann et al., 2001; Belabbassi, 2001; Hamilton and Berger, 2002; Welsh and Inoue, 2002; Krug and Merrifield, 2006; Figs. 1 and 2).

Furthermore, as it travels north, the Western Boundary Current is pressured by and interacts with the Texas/ Louisiana shoreline as its flow bends eastward, promoting much cross-shelf transfer of water off and onto the shelf where hypoxia occurs (Li et al., 1996; Muller-Karger, 2000; Krug and Merrifield, 2006; Figs. 1 and 2). Thus, even though Walsh et al. (1989) estimate appreciable non-MARB N in shelf waters, they overestimate MARB N and underestimate upwelling and upwelling's $\mathrm{N}$ input and enhancement of algal productivity in Louisiana shelf water.

The effect of the inflow of marine nutrients and the resulting displacement of MARB nutrients offshore need to be researched and quantified. Such water transfers affect the results that reductions in MARB $N$ will have on Gulf hypoxia. In a review of the fate of MARB water after it reaches the Gulf, Etter et al. (2004) observe that there has yet to be a study designed to quantify the fate of MARB water e.g. "No detailed climatology of filing and flushing times yet exists for the Texas-Louisiana shelf, it is evident that more research is needed to characterize the fate of Mississippi River discharge in this region" (Etter et al., 2004, p. 18).

Interaction with Atchafalaya River Inputs

The Atchafalaya River discharges at the innermost edge at the broadest part of the continental shelf at the geographic 
centre of the coastline bordering the hypoxic zone (Fig. 2). Changes in the Atchafalaya River are not considered important to hypoxia formation as the amounts and proportion of MARB water and nutrients flowing down the Atchafalaya and the Mississippi have stabilised since the early 1970s (Turner and Rabalais, 1991; Rabalais et al., 1999; Goolsby et al., 1999; CENR, 2000: Kelly et al., 2001). However, the Atchafalaya's impact on the hypoxic zone had yet to stabilise. With the great flood of 1973, a 200 million $\mathrm{m}^{3} \mathrm{yr}^{-1}$ sediment load — the amount of land moved to create the Panama Canal - achieved breakthrough to the Atchafalaya Bay, with 50 percent sediment transfer efficiency to the Gulf outside the bay from where the sediment gets reworked and spread across the continental shelf (Krug, 2007). The new sediment load is so large that whereas, prior to 1973, the coastline of the western half of the hypoxic zone, Atchafalaya Bay itself and estuaries immediately to the east of the bay were losing land, after 1973 land was gained even though most mud was lost offshore and reworked in the Gulf by the erosive forces of wave, wind, current, tide and storm across the continental shelf (Wright, 1977; Roberts et al., 1980; Van Heerden et al., 1981; Wells and Kemp, 1981; Madden et al., 1988; Roberts, 1997). With the 1973 flood came the predicted increased efficiency of sediment transfer through the Atchafalaya and Atchafalaya Bay to the hypoxic zone (Adams and Baumann, 1980; Roberts et al., 1980; Donnell and Letter, 1992; Roberts, 1998; Anonymous, 1999) and the doubling of the extent of Gulf hypoxia by extension westward toward Texas and fuller coverage of the continental shelf west of the Mississippi Trough (Rabalais et al., 1999; CENR, 2000; Krug, 2007; Fig. 2). Gulf hypoxia formed and then expanded with the expansion of mud from the Atchafalaya River (Krug, 2007). The expanding area of fluid mud of the Atchafalaya mud stream and its loose bottom mud on the continental shelf act as fluidised reactor beds where carbon and nutrients are heavily recycled (e.g. Trefry et al., 1994; Aller, 1998; Abril et al., 1999, 2004; Rowe et al., 2002; Gordon and Goni, 2003; Aller et al., 2004; Aller and Blair, 2004; Corbett et al., 2004; McKee et al., 2004; Sutula et al., 2004):

"Fluid muds and mobile surface material cause the seafloor and continental boundary to act as a massive, suboxic, fluidized bed reactor... Reoxidation, repetitive redox successions, metabolite exchange, and continual mixing-in of fresh planktonic debris with refractory terrestrial components, result in an effective decomposition system largely decoupled from net accumulation" (Aller, 1998, p. 143).

Thus with the great flood of 1973, the Atchafalaya mud achieved breakthrough to the coast and permanently altered the coastal dynamics of the hypoxic zone (Roberts et al., 1980; Wells 1980; Wells and Kemp, 1981; 1982; Roberts, 1998; Huh et al., 2001; Draut et al., 2005) creating a large and expanding area of oxygen-consuming fluidised mud reactor to deplete the oxygen from the low volumes of water inherent in these shallow water depths.

The effects of the changing Atchafalaya River, the spread of its sediment load across the dynamic, broad, reactive surface of the continental shelf on which hypoxia forms, are profound (and superimposed on the already recognized input of MARB nutrients); the influence of these sediments on Gulf hypoxia has yet to be researched and quantified.

\section{Interaction with Mississippi River Inputs}

The calculated effect of the Mississippi River discharge on Gulf hypoxia is based on idealised conditions: "Of the discharge from the Mississippi River delta, approximately 53\% flows westward onto the Louisiana shelf (U.S. Army Corps of Engineers 1974, Dinnel and Wiseman 1986)" (Rabalais et al., 1999, p. 34).

The origin of this statement is Dinnel's 1984 M.Sc. thesis (Dinnel, 1984). U.S. Army Corps of Engineers 1974 data are the authority to determine the percentage of Mississippi River water that flows out through which outlet to the Gulf. South Pass, Southwest Pass and Grand and Tiger Passes add up to 53 percent of total flow and all of this water is assumed to flow west (Dinnel, 1984). Dinnel and Wiseman (1986) state that 53 percent of the Mississippi's discharge is assumed to move west. From this, Turner and Rabalais (1991) assumed that 53 percent of Mississippi River water supports algal production in $106866 \mathrm{~km}^{2}$ of USA continental shelf water west of the Mississippi (Turner and Rabalais, 1991): an assumption retained by the hypoxia assessment (Rabalais et al., 1999, p. 35) upon which the Action Plan is based significantly. However, these idealised conditions are not approached in nature. There is much transfer of water on and off the continental shelf and this is especially the case with the Mississippi River. The Mississippi River discharges from the end of a land bridge which extends clear across the continental shelf. This water discharged beyond the shelf break (e.g. Ohlmann et al., 2001; Swarzenski, 2001; Fig. 2) often flows east and south as well as west (Lyell, 1849; Humphreys and Abbott, 1876; Woodring, 1936; Scruton, 1956; Maul, 1974; Atkinson and Wallace, 1975; Rouse and Coleman, 1976; Crout et al., 1984; Sturges, 1993; Dowgiallo, 1994; Li et al., 1997; Cho et al, 1998; Conkright et al., 1999; He and Weisberg, 2002; Welsh and Inoue, 2002; Morey et al., 2003a,b; Krug and Merrifield, 2006).

The eastward-flowing Boundary Current also confounds calculations based on idealised conditions because when the Mississippi River's outflow actually does flow westward 
it often gets blocked as it runs into this much larger eastward flow of water. As the Boundary Current approaches the far (eastern) end of the hypoxic zone, it 'hits a wall', the land bridge built by the Mississippi River:

"The large-scale geometry of the coast is not only of geomorphic interest but also of importance in determining large-scale flow patterns. The $80-\mathrm{km}$ protrusion of the Mississippi delta into the Gulf of Mexico is exceeded perhaps only by Cape Cod in its ability to alter and affect the current, tidal, and wave fields operating in the local coastal waters" (Murray, 1976, p. 1).

While not perfectly contained due to the seasonal westward flow of the alongshore Louisiana Coastal Current, there is four-way convergence of surface waters over the Mississippi Trough (Fig. 2): outflows of the Atchafalaya and Mississippi Rivers, outflows of the Barataria and Terrebonne estuaries, and inflow of clear Gulf water. Convergence removes surface water by physically forcing it downward (Woodring, 1936; Ichiye, 1960; Conatser, 1971; Penland and Boyd, 1985; Levin, 1991; Hitchcock et al., 1997; 2004; Krug and Merrifield, 2006). This forcing is further enhanced by the nature of the clash of river, estuary and seawaters inherent in the area around the Mississippi. The physicochemical process known as 'cabbeling' mixes masses of water of different temperatures and salinities to produce water denser than the components of its parts. Cabbeling produces vertical velocities that may be thousands of times greater than typical open water values. As distinguished by the extreme upwelling of Loop Current water around the Mississippi River Delta, seawater is advected from depth to replace seawater that mixes with freshwater (Uda, 1938; Garvine and Monk, 1974; Bowman, 1978; Bowman and Iverson, 1978; Pingree et al., 1978; Govoni and Grimes, 1992; Beer, 1997; Hitchcock et al., 1997; Stanton and Ostrovsky, 1998; Moum et al., 2003; Nash and Moum, 2005). These conditions make the Mississippi River Delta area a locus of convergence, cabbeling and subduction of freshwater. Ichiye (1960) noted that in the area around the Mississippi River delta $\left(27^{\circ}-30^{\circ}\right.$ latitude and $87^{\circ}-92^{\circ}$ longitude) "the salinity in the upper layers is so variable that the average picture obtained by simply putting together all data available seems to be meaningless" (p. 71).

"At the continental slope near the mouth of the Mississippi...the temperature at a depth of $100 \mathrm{~m}$ changed by $2^{\circ}-3^{\circ}$ within a few hours...obviously a result of internal waves associated with the tides. It is clear that this region is very dynamic. In the open sea the temperature fluctuations within the same period were within the range of $1^{\circ}$ " (Bogdanov, 1965, p. 19).

Analysis of 1471 Gulf water profiles down to $1000 \mathrm{~m}$ depth from April 1998 to December 2002 (Weatherly et al., 2003) show that freshwater from the Mississippi River is subducted into the depths (1000 m or more) of the Gulf 867 inversions were found in the 1471 profiles. Of these inversions, 96 percent were seen above $160 \mathrm{~m}$ depth. Average depth was $32 \mathrm{~m}$. Inversions clustered within $400 \mathrm{~km}$ of the Mississippi River and inversions persisted over time and space, indicating large volumes of water. The floats used to measure inversions typically drifted several $10 \mathrm{~s}$ of $\mathrm{km}$ a day in their 7-day cycles and inversions commonly persisted through the 7 days (Weatherly et al., 2003). Temperature and/or salinity inversions also were seen by others (e.g. Dodge and Lang, 1983; Brooks and Legeckis, 1982; LugoFernandez, 1998; Conkright et al., 1999; Wawrik and Paul, 2004). Clearly nutrients in such subducted Mississippi River water are not available to support algal growth at the surface of the hypoxic zone.

Overall, currents of the continental shelf induce manifolds through which off-shelf water is advected onto the shelf and shallow shelf waters are advected offshore and down into waters up to $2000 \mathrm{~m}$ deep (Hunter, 2001). Coastal freshwater outbreaks in the north-west Gulf of Mexico can be of the order of the entire current flow through the Gulf of Mexico, over $30 \times 10^{6} \mathrm{~m}^{3} \mathrm{sec}^{-1}$, which is more than 600 times the instantaneous flow of the MARB to the Gulf of Mexico (Brooks and Legeckis, 1982). The area around the Mississippi River Delta is a locus of onshore/offshore transfer of water (Ohlmann et al., 2001) where marine nutrients become available to support algal growth and where river water is no longer available to support algal growth.

For the Boundary Current there is such a manifold favouring offshore and onshore flow of water in front of and parallel to the land bridge built by the Mississippi. The two most prominent physiographic features of the region, the Mississippi River Delta and the Mississippi Canyon/ Trough (e.g. Coleman et al., 1982, p. 519), are in close proximity and parallel each other. The Canyon has extended itself inland as a trough almost to the shoreline of the Timbalier and Barataria estuaries just west of the Mississippi River delta and it has extended itself offshore as the major sediment fan of the Gulf of Mexico. The Mississippi Trough and Mississippi Canyon are a by-pass system that feeds the mud-rich Mississippi Fan which lies at the bed of the Gulf of Mexico (e.g. Stuart and Caughey, 1976; La Blanc and Steffens, 1986; Burden, 1999; Nelson 2002; Nelson et al., 2002). Bathymetry dating back to the 1700 s (United States Coast Survey, 1861, 1863; Fig. 1) and modern sediment sampling (Corbett et al., 2004; McKee et al., 2004) indicate that these dynamic currents have maintained the Mississippi Trough essentially as is. It has been maintaining its features 
while accumulating just enough sediment to compensate for land subsidence in the face of a river system that delivers nearly 20 times the sediment load of all of the rivers on the entire East Coast of the United States, 70-75 percent of which is directed to the west toward the direction of the trough (Scruton, 1956; Curtis et al., 1973). Radioisotope studies show that this sediment is being deposited within $30 \mathrm{~km}$ of the Mississippi River Delta (Corbett et al., 2004; McKee et al., 2004). Similarly, there is a sharp decline in both algal productivity and dissolved nutrient content of Mississippi River water; as with the river's sediment, the bulk of the algae produced by Mississippi River water settle here (Riley, 1937; Thomas and Simmons, 1960; Lohrenz et al., 1990, 1997, 1999; Lopez-Veneroni and Cifuentes, 1994; Smith and Hitchcock, 1994; Rabalais et al., 1996, 1999; Scavia et al., 2003) to be, like the bulk of the terrestrial sediment deposited here, transported offshore and downslope into the deeps of the Gulf of Mexico.

As noted by Goodbred and Kuehl (1999), troughs and canyons persist near the mouths of rivers delivering great loads of sediment by actively depositing sediment offshore. The conclusion derived from the existence of the canyon in an otherwise extremely flat continental shelf (e.g. Scruton, 1956; Stuart and Caughey, 1976; Darnell et al., 1983; National Ocean Service, 1985) in the high sediment deposition area immediately to the west of the Mississippi River is that this is a preferential area of offshore movement of sediment as well as water.

The effect of the Boundary Current/Mississippi Delta/ Mississippi Canyon system's transport of water, dissolved nutrients, sediment and organic matter away from the hypoxic zone has yet to be researched and quantified.

Spring/Summer Although eastward movement of discharged Mississippi River water away from the hypoxic zone can occur at all times of the year, the warm months are a special case where eastward movement is common and can predominate. For six months of the spring and summer the prevailing winds of the Bermuda High strengthen the eastward flow of the Boundary Current and act to drive nearshore waters, the Louisiana Coastal Current, eastward and away from the Mississippi Trough (Scruton, 1956; Linton, 1968; Murray, 1976; Blaha and Sturges, 1978; Oetking et al., 1979a; Bedinger et al., 1981; Sklar and Turner, 1981; Crout and Hamiter, 1981; Halper et al., 1988, Martinez-Lopez and Pares-Sierra, 1998; Wang et al., 1998; Chen et al., 2000; Lugo-Fernandez et al., 2001; Welsh and Inoue, 2002). Its prevalent summertime eastward movement along the Louisiana shelf can be viewed on the hundreds of satellite images displayed by Krug and Merrifield (2006).

This shift to easterly flows has long been recognized as being biologically significant. For example, as part of an expanded NOAA research effort into the Gulf shrimp fishery (Kutkuhn, 1963), extensive research was conducted on currents along the USA Gulf coast (Temple and Martin, 1979). This NOAA research found there was a seasonal pattern in currents induced by seasonal changes in prevailing winds, citing 11 previous studies in support of this observation of seasonal eastward flow (Temple and Martin, 1979). Furthermore: "Physical oceanographers have suspected the Mississippi River (MR) as a source of lowsalinity water in the Gulf Stream and Florida Straits (Wennekens, 1959; Atkinson and Wallace, 1975; Maul, 1974)..." (Ortner et al., 1995). This 'Green River' of chlorophyll-enriched, freshened water was observed at least as early as 1962 (Khromov, 1965, p. 39). Since the 1970s, satellite observations have come to supplement traditional observations of the Green River, the movement of Mississippi River water east from its outlet and as far down as into and through the Florida Straits (Maul, 1977; Ortner et al., 1984; Muller-Karger et al., 1991; Gilbes et al., 1996; Wang et al., 1998; Chen et al., 2000; Paul et al., 2000a,b; Muller-Karger, 2000; Del Castillo et al., 2001; He and Weisberg, 2002; Hu et al., 2003; Morey et al., 2003a,b; Toner et al., 2003; Wawrik et al., 2003; 2004; Wawrik and Paul, 2004; Krug and Merrifield, 2006). During the warm season, Mississippi River water does not typically attach itself to the coast west of the Mississippi River delta to move west in the Louisiana Coastal Current (Rabalais et al., 1999, p. 33). Indeed, the prevalent seasonal movement of the Louisiana Coastal Current is east toward the Mississippi River.

These findings show that the previously held view overemphasised the effect of the Mississippi River in creating and sustaining a warm season cap of water under which hypoxia forms. They also show that there is less Mississippi River $\mathrm{N}$ and other nutrients than is calculated to support algal production in the hypoxic zone in the warm season. These findings need to be further developed and integrated into calculations of the effects of MARB N, nutrients and water on Gulf hypoxia.

Interaction with Barataria and Terrebonne estuarine inputs The basins containing the Barataria and Terrebonne estuaries are exemplars of nutrients and organic matter stored over thousands of years that are bleeding into the hypoxic zone from massive wetland loss: 80 percent of tidal wetland loss for the entire continental USA occurs in the Mississippi River Delta (Roberts, 1994). Barataria Bay occupies about 10 percent of the coastline of the hypoxic zone. By the early 1970s, Barataria Bay was estimated to be imposing an oxygen demand on coastal waters equal to that of total net primary productivity of the hypoxic zone itself through a 
net daily flushing of 230 million $\mathrm{m}^{3}$ day $^{-1}$ (Happ et al., 1977; Krug, 2007). Since then, Barataria Bay has almost doubled in size and is still growing. Barataria and Terrebonne Bays occupy about 30 percent of the shoreline of the hypoxic zone and their combined daily outflow to the Gulf was estimated to be about three times that of the Barataria alone (Swenson and Swarzenski, 1995). Both basins continue to lose land and their bays continue to grow (Martin et al., 2000; USGS, 2003): "The escalating volume of freshened and warmed estuarine water being flushed daily into the hypoxic zone changes coastal hydrology to increasingly favor the development of hypoxia. This increasinglyfavorable hydrology combined with the outflow of hundreds-to-thousands of years of accumulated oxygenconsuming nutrients and organic matter, and highly productive estuarine water, all act in concert to increasingly promote hypoxia as marine transgression progresses along the disintegrating coastal lands of the eastern half of the hypoxic zone" (Krug, 2007).

Unlike the Mississippi River, whose outlets discharge beyond the shelf break and into the face of the Boundary Current, the outlets of Barataria and Terrebonne Bays discharge on the innermost side of the continental shelf and, therefore, should be more effective in promoting hypoxia than Mississippi River water by movement east and west in the Louisiana Coastal Current. On the other hand, since the Mississippi Trough approaches the outlets of both estuaries, there will also be interaction between the trough and estuarine outflows. Thus, it is expected that water, nutrients and sediments discharged from these basins will be less effective in promoting hypoxia west of the Mississippi Trough than that discharged by the Atchafalaya River as these estuaries are located immediately in front of an oceanographic manifold favouring offshore/onshore flow: "Brackish water plumes in shelf water and their mass continuity counterpart, landward flowing shelf bottom water, are both powerful components of the more general coupled circulation between estuaries and the continental shelf. Because of the very low frequencies at which they operate, including the climatological mean state, they contribute greatly to net displacement of water and thus are both certain to exert critical impacts on both estuarine and shelf ecology" (Garvine, 1986, p. 64).

The effect of the changing hydrology, nutrient and material from wetland loss on Gulf hypoxia has yet to be adequately researched and quantified.

\section{Conclusions}

This study builds upon a companion study (Krug, 2007) by applying a Gulf of Mexico perspective to the hypoxic zone; how the Gulf processes inputs from the MARB and coastal change, and how the Gulf interacts with coastal change. In doing so, assumptions used to define the Gulf hypoxia problem were further examined. The MARB supplies 1.6 million metric tons ${\mathrm{N} \mathrm{yr}^{-1}}^{-1}$ to the 230 million metric tons $\mathrm{NO}_{3}-\mathrm{N}$ which flows through the Gulf every year, of which 120 million metric tons $\mathrm{NO}_{3}-\mathrm{N}$ is upwelled. Whereas calculations of the MARB's effect on Gulf hypoxia assume that MARB N is the only source of N for the $106866 \mathrm{~km}^{2}$ of the continental shelf water between the Mississippi and the Mexican border, this was found not to be the case. The Western Boundary Current, Loop Current and wind-derived currents favour upwelling onto the Texas and Louisiana continental shelf and/or downwelling and offshore transport of shelf water. Upwelling and offshelf/onshelf water transfers are most favoured along the Louisiana coast and it is here that marine nutrient inputs are favoured to support algal production and where loss of MARB nutrients offshore is also favoured.

The Gulf of Mexico's oceanography minimises the relative effectiveness of the Mississippi River inputs on Gulf hypoxia. The above-calculated effect of Mississippi River discharge on Gulf hypoxia is based on the idealised assumption that all water discharged from the Atchafalaya and from the Mississippi's South Pass, Southwest Pass, and Grand and Tiger Passes, 53 percent of the Mississippi's total flow, flows west to support algal production in the 106866 $\mathrm{km}^{2}$ of USA continental shelf water west of the Mississippi. Nevertheless, the Mississippi River discharges from the end of a land bridge which extends clear across the continental shelf to discharge much of its waters beyond the shelf break. Out here, discharged waters flow east and south as well as west. During the summertime when hypoxia occurs, predominant flow is east, away from the hypoxic zone. Water that does move west runs into the Gulf's Boundary Current. The convergence of Gulf and river waters has maintained the Mississippi Trough through the forcing of water, sediment and decaying algae downtrough and offshelf. Such water, nutrients and organic matter are unavailable to support hypoxia.

Oceanographic factors enhance the Atchafalaya's influence on Gulf hypoxia. Most hypoxia occurs on the broad, flat, shallow continental shelf west of the Mississippi Trough and it is here that the extent of hypoxia has expanded. Atchafalaya River water, nutrients and sediments discharge into the innermost edge of the broadest part of the continental shelf at the hypoxic zone's geographic centre. Water, nutrients and sediment are spread east, west and south throughout the hypoxic zone. Starting with its sediment load breakthrough during the 1973 flood, and its enhancement with the 1993 flood, Atchafalaya River mud has been 
expanding along the coast and along the bottom of the hypoxic zone. The expanding area of fluid mud is acting as an expanding fluidised reactor bed where carbon and nutrients are heavily recycled, depleting DO from the relatively small volumes of overlying shallow water. And with this expansion of reactive fluidised mud, Gulf hypoxia has also been expanding, superimposing its effects upon the MARB influences already recognised.

The oceanographic controls on water, nutrient and sediment output from the Barataria and Terrebonne estuaries appear to be intermediate between that of the Mississippi and Atchafalaya Rivers. Whereas these estuaries discharge at the innermost part of the continental shelf, they do so at the eastern edge of where hypoxia forms and into the mouth of the Mississippi Trough which lies just offshore of their outlets.

It is recommended that a broadened approach for better understanding the causes and controls of Gulf hypoxia be adopted including, but not limited to, MARB inputs and coastal change and marine processing of terrestrial and Gulf influences.

\section{References}

Abril, G., Commarieu, M.-V., Maro, D., Fontugne, M., Guerin, F. and Etcheber, H., 2004. A massive dissolved inorganic carbon release at spring tide in a highly turbid estuary. Geophys. Res. Lett., 31, L09316. 4pp.

Abril, G., Etcheber, H., Le Hir, P., Bassoulett, P., Boutier, B. and Frankignoulle, M., 1999. Oxic/anoxic oscillations and organic carbon mineralization in an estuarine maximum turbidity zone (The Gironde, France). Limnol. Oceanogr., 44, 1304-1315.

Adams, R.D. and Baumann, R.H., 1980. Land building in coastal Louisiana: emergence of the Atchafalaya Bay delta. Sea Grant Publ. No. LSU-T-80-02. Louisiana State University, Baton Rouge, LA, USA. 26pp. plus appendix.

Allen, R.L., Turner, R.E. and Day, J.W., Jr., 1984. Oyster Management and Environmental Influences in the Gulf of Mexico, 1880-1978. Louisiana State University, Baton Rouge, LA, USA. $127 \mathrm{pp}$.

Aller, R.C., 1998. Mobile deltaic and continental shelf muds as suboxic, fluidized bed reactors. Mar. Chem., 61, 143-15.

Aller, R.C. and Blair, N.E., 2004. Early diagenetic demineralization of sedimentary organic $\mathrm{C}$ in the Gulf of Papua deltaic complex (Papua New Guinea): net loss of terrestrial C and diagenetic fractionation of $\mathrm{C}$ isotopes. Geochim. Cosmochim. Acta, 68, 1815-1825.

Aller, R.C., Heilbrun, C., Panzeca, C., Zhu, Z. and Baltzer, F., 2004. Coupling between sedimentary dynamics, early diagenetic processes, and biogeochemical cycling in the Amazon-Guianas mobile mud belt: coastal French Guiana. Mar. Geol., 208, 331360 .

Anikouchine, W.A. and Sternberg, R.W., 1973. The World Ocean: an Introduction to Oceanography. Prentice-Hall, Englewood Cliffs, NJ, USA. 338pp.

Anonymous, 1999. Louisiana returns natural flow to the delta, creates wetlands. Civil Eng., February 1999, 26.

Atkinson, L.P. and Wallace, D., 1975. The source of unusually low surface salinities in the Gulf stream off Georgia. Deep Sea Res., 23, 913-916.
Bates, C.C., 1953a. Rational theory of delta formation. Amer. Assoc. Petrol. Geol. Bull., 37, 2119-2162.

Bates, C.C., 1953b. A rational theory of delta formation as exemplified by the present-day Mississippi delta. J. Sed. Petrology, 23, 132-133.

Bedinger, C.A., Jr., Childers, R.E., Cooper, J.W., Kimball, K.T. and Kwok, A., 1981. Ecological Investigations of Petroleum Production Platforms in the Central Gulf of Mexico-Volume I, Part 1,2,3. In: Ecological Investigations of Petroleum Production Platforms in the Central Gulf of Mexico-Volume I-VI, C.A. Bedinger, Jr. (Ed.). National Technical Information Service, Springfield, VA, USA. various paging.

Beer, T., 1997. Environmental Oceanography. Second Edition. CRC Press, Boca Raton, FL, USA. 367pp.

Belabbassi, L., 2001. Importance of Physical Processes on NearSurface Nutrient Distributions in Summer in the Northeastern Gulf of Mexico. M. Sc. Thesis, Texas A \& M University, College Station, TX, USA. 75pp.

Bender, M.E., Reisch, D.J. and Ward, C.H., 1979. Re-examination of the offshore ecology investigation. Rice University Studies, 65, 35-102.

Berner, R.A., 1982. Burial of organic carbon and pyrite sulfur in the modern ocean: its geochemical and environmental significance. Amer. J. Sci., 282, 451-473.

Biggs, D.C., Fargion, G.S., Hamilton, P. and Leben, R.R., 1996. Cleavage of a Gulf of Mexico Loop Current eddy by a deep water cyclone. J. Geophys. Res., 101, 20,629-20,641.

Blaha, J.P. and Sturges, W., 1978. Evidence for Wind Forced Circulation in the Gulf of Mexico. Department of Oceanography, Florida State University, Tallahassee, FL, USA. 134pp.

Boesch, D.F., 1999. The role of the Mississippi River in Gulf of Mexico hypoxia: oversimplifications and confusion. In: Hypoxia in the Gulf of Mexico: progress towards the completion of an Integrated Assessment. Public Comments. NOAA's National Centers for Coastal Ocean Science Gulf of Mexico Hypoxia Assessment. Website: http://www.nos.noaa.gov/products/ hyxpcdia boesch.pdf (Accessed 22 March 2006).

Bogdanov, D.V., [1965] 1969. Some oceanographic features of the Gulf of Mexico and the Caribbean Sea. In: Soviet-Cuban Fishery Research, A.S. Bogdanov (Ed.), Israel Program for Scientific Translations, Jerusalem, Israel. Translated from Sovetsko-Kubinskie rybokhozyaistvennye issledovaniya, Izdatel'stvo "Pishchevaya Promyshlennost', Moskva 1965. 1335.

Bourne, J., 2000. Louisiana's vanishing wetlands: going, going.... Science, 289, 1860-1863.

Bowman, M.J., 1978. Introduction and historical perspective. In: Oceanic Fronts in Coastal Processes. Proc. Workshop held at the Marine Sciences Research Center, May 25-27, 1977, M.J. Bowman and W.E. Esaias (Eds.), Springer-Verlag, Berlin, Germany. 2-5.

Bowman, M.J. and Iverson, R.L., 1978. Estuarine and plume fronts. IN: Oceanic Fronts in Coastal Processes. Proc. Workshop held at the Marine Sciences Research Center, May 25-27, 1977. M.J. Bowman and W.E. Esaias (Eds.), Springer-Verlag, Berlin, Germany. 87-104.

Bringier, L., 1821. Notices of the geology, mineralogy, topography, productions, and aboriginal inhabitants of the regions around the Mississippi and its confluent waters. Amer. J. Sci., 3, 1546.

Britsch, L.D. and Dunbar. J.B., 1993. Land loss rates: Louisiana coastal plain. J. Coastal Res., 9, 324-338.

Brooks, D.A. and Legeckis, R.V., 1982. A ship and satellite view of hydrographic features in the western Gulf of Mexico. $J$. Geophys. Res., 87, 4195-4206. 
Burden, C.A., 1999. Sediment transport in the Mississippi Canyon: the role of currents and storm events on optical variability. M.Sc. thesis, Texas A\&M University, College Station, TX, USA. $120 \mathrm{pp}$.

Caddy, J., 1993. Toward a comparative evaluation of human impacts on fishery ecosystems of enclosed and semi-enclosed seas. Rev. Fish. Sci., 1, 57-96.

Capone, D.G. and R.P. Kiene, R.P., 1988. Comparison of microbial dynamics in marine and freshwater sediments: contrasts in anaerobic carbon catabolism. Limnol. Oceanogr., 33, 725-749.

CENR, 1995. Setting a New Course for U.S. Coastal Ocean Science: Final Report of the Subcommittee on U.S. Coastal Ocean Science. National Science and Technology Council, Committee on Environment and Natural Resources, Washington, DC, USA. $111 \mathrm{pp}$. Website: http://purl.access.gpo.gov/GPO/ LPS25823. (Accessed 11 August 2005).

CENR, 1998. Gulf of Mexico Hypoxia Assessment Plan. Committee on Environment and Natural Resources Hypoxia Working Group, Office of Science and Technology, Executive Office of the President, Washington, DC, USA. 13pp.

CENR, 2000. Integrated Assessment of Hypoxia in the Northern Gulf of Mexico. National Science and Technology Council Committee on Environment and Natural Resources, Washington, DC, USA. 66pp. Website: http://www.nos.noaa.gov/products/ pubs hypox.html. (Accessed 11 August 2005).

Chabreck, R.H., 1972. Vegetation, water and soil characteristics of the Louisiana Coastal Region. Louisiana State University/ Agricultural Experiment Station Bulletin No. 664. Louisiana State University, Baton Rouge, LA, USA. 72pp.

Chabreck, R.H. and Linscombe, R.G., 1982. Changes in vegetative types in Louisiana coastal marshes over a 10-year period. Proc. Louisiana Acad. Sci., 45, 98-102.

Chen, X., Lohrenz, S.E. and Wiesenburg, D.A., 2000. Distribution and controlling mechanisms of primary production on the Louisiana-Texas continental shelf. J. Mar. Syst., 25, 179-207.

Chen, N-H, Bianchi, T.S., McKee, B.A. and Bland, J.M., 2001. Historical trends of hypoxia on the louisiana shelf: application of pigments as biomarkers. Org. Geochem., 32, 543-561.

Chew, F., Drennan, K.L. and Demoran, W.J., 1962. Some results of drift bottle studies off the Mississippi delta. Limnol. Oceanogr. 7, 252-257.

Cho, K., Reid, R.O. and Nowlin, W.D., Jr., 1998. Objectively mapped stream function fields on the Texas-Louisiana shelf based on 32 months of moored current meter data. J. Geophys. Res., 103, 10377-10390.

Cochrane, J.D. and Kelly, F.J., 1986. Low-frequency circulation on the Texas-Louisiana continental shelf. J. Geophys. Res. 91, 10,645-10,659.

Coleman, J.M., 1988. Dynamic changes and processes in the Mississippi River delta. Geol. Soc. Amer. Bull., 100, 999-1015.

Coleman, J.M., Prior D.B. and Lindsay, J.F., 1982. Formation of the Mississippi Canyon. Gulf Coast Ass. Geol. Soc. Trans., 32, 519.

Conatser, W.E., 1971. Grand Isle: a barrier island in the Gulf of Mexico. Geol. Soc. Amer. Bull. 82, 3049-3068.

Conkright, M., Levitus, S., O’Brien, T, Boyer, T., Antonov, J. and Stephens, C., 1999. World Ocean Atlas 1998 Figures. National Oceanic and Atmospheric Administration, Washington DC, USA. 3 computer optical discs.

Cooper, S.R. and Brush, G.S., 1991. Long-term history of Chesapeake Bay anoxia. Science, 254, 992-996.

Corbett, D.R., McKee, B. and Duncan, D., 2004. An evaluation of mobile mud dynamics in the Mississippi River deltaic region. Mar. Geol., 209, 91-112.
Coveney, R.M., Jr., Watney, W.L. and Maples, C.G., 1991. Contrasting depositional models for Pennsylvanian black shale discerned from molybdenum abundances. Geology, 19, 147150.

Crout, R.L. and Hamiter, R.D., 1981. Response of bottom waters on the west Louisiana shelf to transient wind events and resulting sediment transport. Gulf Coast Ass. Geol. Soc., 31, 273-278.

Crout, R.L., Wiseman, W.J., Jr. and Chuang, W.-S., 1984. Variability of wind-driven currents, west Louisiana inner continental shelf: 1978-1979. Contrib. Mar. Sci., 27, 1-11.

Curtis, W.F., Culbertson, J.K. and Chase, E.B., 1973. Fluvialsediment discharge to the oceans from the conterminous United States. U.S. Geologic Survey Circ. 670. U.S. Geological Survey, Reston, VA, USA. 17pp.

Darnell, R.M., Defenbaugh, R.E. and Moore, R.R., 1983. Northwestern Gulf Shelf Bio-atlas: a study of the distribution of demersal dishes and Penaeid shrimp of soft bottoms of the continental shelf from the Rio Grande to the Mississippi River delta. Minerals Management service Open File Report 82-04. Minerals Management Service, Metairie, LA, USA. 438pp.

Davies, D.K. and Moore, W.R., 1970. Dispersal of Mississippi sediment in the Gulf of Mexico. J. Sed. Petrol., 40, 339-353.

Day, J.W., Jr., Smith, W.G., Wagner, P.R. and Stowe, W.C., 1973. Community Structure and Carbon Budget of a Salt Marsh and Shallow Bay Estuary System in Louisiana. LSU-SG-72-04. Louisiana State University, Baton Rouge, LA, USA. 80pp.

Day, J.W., Jr., Pont, D., Hensel, P.F. and Ibanez, C., 1995. Impacts of sea-level rise on deltas in the Gulf of Mexico and the Mediterranean: the importance of pulsing events to sustainability. Estuaries, 18, 636-647.

Del Castillo, C.E., Coble, P.G., Conmy, R.N., Muller-Karger, F.E., Vanderbloemen, L. and Varga, G.A., 2001. Multispectral in situ measurements of organic matter and chlorophyll fluorescence in seawater: Documenting the intrusion of the Mississippi River plume in the West Florida Shelf. Limnol. Oceanogr., 46, 18361843.

Diaz, R. and A. Solow. 1999. Ecological and Economic Consequences of Hypoxia. White House, OSTP, CERN Hypoxia Working Group, Topic 2 Report. NOAA Coastal Ocean Program Decision Analysis Series No. 16. NOAA Coastal Ocean Program, Silver Spring, Maryland, USA. 46pp. Website: http:/ /www.nos.noaa.gov/products/pubs hypox.html. (Accessed 11 August 2005)

Dinnel, S.P., 1984. Distribution and residence time of freshwater on the west Louisiana and Texas continental shelves. Louisiana State University, Baton Rouge, LA, ,USA. 89pp.

Dinnel, S.P. and Wiseman, W.J., Jr., 1986. Fresh water on the Louisiana and Texas shelf. Continental Shelf Res., 6, 765-784.

Dodge, R.E. and Lang, L.C., 1983. Environmental correlates of hermatypic coral (Montastrea annularis) growth on the East Flower Gardens Bank, northwest Gulf of Mexico. Limnol. Oceanogr., 28, 228-240.

Doering, O.C., Diaz-Hermelo, F., Howard, C., Heimlich, R., Hitzhusen, F., Kazmierczak, R., Lee, J., Libby, L., Milon, W., Prato, T. and Ribaudo, M., 1999. Evaluation of the economic costs and benefits of methods for reducing nutrient loads to the Gulf of Mexico. Topic 6 Report for the Integrated Assessment on Hypoxia in the Gulf of Mexico. NOAA Coastal Ocean Program Decision Analysis Series No. 20. NOAA Coastal Ocean Program, Silver Spring, M, USA. 116pp. Website: http:// www.nos.noaa.gov/products/pubs hypox.html. (Accessed 11 August 2005).

Donnell, B.P. and Letter, J.V., Jr., 1992. The Atchafalaya River delta. Report 13, summary report of delta growth predictions. Tech. Rept. HL-82-15. US Army Corps of Engineers, Waterways Experiment Station, Vicksburg, MS, USA. 63pp. plus figure and appendix. 
Dowgiallo, M.J., 1994. Preface. In: Coastal Oceanographic Effects of 1993 Mississippi River Flooding, M.J. Dowgiallo (Ed.). Special NOAA report. NOAA Coastal Ocean Office/National Weather Service, Silver Spring, MD, USA.

Draut, A.E., Kineke, G.C., Huh, O.K., Grymes, J.M., III, Westphal, K.A. and Moeller, C.C., 2005. Coastal mudflat accretion under energetic conditions, Louisiana chenier-plain coast, USA. Mar. Geol., 214, 27-47.

Ellis, M.M., 1931. Some factors affecting the replacement of commercial fresh-water mussels. U.S. Dept. Commerce Bureau of Fisheries Fishery Circular No. 7. U.S. Government Printing Office, Washington, DC, USA. 10pp.

Etter, P.C., Howard, M.K. and Cochrane, J.D., 2004. Heat and freshwater budgets of the Texas-Louisiana shelf. J. Geophys. Res., 109, C02024, doi:10.1029/2003JC001820.

Fails, T.G., 1990. The Northern Gulf Coast basin: a classic petroleum province. In: Classic Petroleum Provinces, J. Brooks (Ed.). Geological Society Spec. Publ. No. 50. The Geological Society, London, UK. 221-248.

Fair, G.M., Moore, E.W. and Thomas, H.A., Jr., 1941. The natural purification of river muds and pollutional sediments. Sewage Works J., 13, 270-307.

Farrell, D.H., 1979. Benthic molluscan and crustacean communities in Louisiana. Rice University Studies, 65, 401436.

Feijtel, T.C., DeLaune, R.D. and Patrick, W.H., Jr., 1985. Carbon flow in coastal Louisiana. Mar. Ecol. Progr. Ser., 24, 255-260.

Fischer, H.B., List, E.J., Koh, R.C.Y., Imberger, J. and Brooks, N.H., 1979. Mixing in Inland and Coastal Waters. Academic Press, New York, New York, USA. 483pp.

Fisk, H.N., 1952. Geologic Investigation of the Atchafalaya Basin and the Problem of Mississippi River Diversion. US Army Corps of Engineers, Vicksburg, MS, USA. 145pp.

Fisk, H.N., and McFarlan, E., Jr., 1955. Late Quaternary deltaic deposits of the Mississippi River: local sedimentation and basin tectonics. In: Crust of the Earth. A Symposium, A. Poldervaart (ed.). Geological Society of America Special Paper 62. Geological Society of America, Boulder, CO, USA. 279-302.

Fisk, H.N., McFarlan, E., Jr., Kolb, C.R. and Wilbert, L.J., Jr., 1954. Sedimentary framework of the modern Mississippi delta. J. Sed. Petrology, 24, 76-99.

Fremling, C.R., Rasmussen, J.L., Sparks, R.E., Cobb, S.P., Bryan, C.F. and Claflin, T.O., 1989. Mississippi River fisheries: a case history. In: Proceedings of the International Large Rivers Symposium (LARS), D.P. Dodge (Ed.). Can. Spec. Publ. Fish. Aquat. Sci. 106, 309-351.

Fucik, K.W., 1974. The Effect of Petroleum Operations on the Phytoplankton Ecology of the Louisiana Coastal Waters. M.Sc. thesis, Texas A \& M University, College Station, TX, USA. 82pp.

Gagliano, S.M., Light, P. and Becker, R.E., 1973. Controlled diversions in the Mississippi delta system: an approach to environmental management. Hydrologic and Geologic Studies of Coastal Louisiana Report No. 8. Louisiana State University, Baron Rouge, LA, USA. 146pp.

Gardner, W.S., Seitzinger, S.P. and Malczyk, J.M., 1991. The effects of sea salts on the forms of nitrogen released from estuarine and ferhwater sediments: does ion pairing affect ammonium flux? Estuaries, 14, 157-166.

Garvine, R.W., 1986. The role of brackish plumes in open shelf waters. In: The Role of Freshwater Outflow in Coastal Marine Ecosystems, S. Skreslet (Ed.), Springer-Verlag, Berlin, Germany. 47-65.

Garvine, R.W. and Monk, J.D., 1974. Frontal structure of a river plume. J. Geophys. Res., 79, 2251-2259.
Gaston, G.R., 1985. Effects of hypoxia on macrobenthos of the inner shelf off Cameron, Louisiana. Estuar. Coast. Shelf Sci., 20, 603-613.

Genger, D. and Sethi, P., 1998. A geochemical and sedimentological investigation of high-resolution environmental changes within the Late Pennsylvanian (Missourian) Eudora Core Black Shale of the Mid-Continent Region, U.S.A. In: Shales and Mudstones. Volume 1. Basin Studies, Sedimentology, and Paleontology, J. Schieber, W. Zimmerle, and P.S. Sethi (Eds.). E. Schweizerbart'sche Verlagsbuchhandlung (Naglele u. Obermiller), Stuttgart, Germany. 271-293.

George, C.J., 1972. The role of the Aswan High Dam in changing the fisheries of the southeastern Mediterranean. In: The Careless Technology. Ecology and International Development, M.T. Farvar and J.P. Milton (Eds.), The Natural History Press, Garden City, New York, USA. 159-178.

Gilbes, F., Tomas, C., Walsh, J.J. and Muller-Karger, F.E., 1996. An episodic chlorophyll plume on the West Florida Shelf. Cont. Shelf Res. 16, 1201-1224.

Goodbred, S.L. and Kuehl, S.A., 1999. Holocene and modern sediment budgets for the Ganges-Brahmaputra river system: evidence for highstand dispersal to flood-plain, shelf, and deepsea depocenters. Geol., 27, 559-562.

Goolsby, D.A., Battaglin, W.A., Lawrence, G.B., Artz, R.S., Aulenbach, B.T., Hooper, R.P., Keeney, D.R. and Stensland, G.J., 1999. Flux and Sources of Nutrients in the MississippiAtchafalaya River Basin. Topic 3 Report for the Integrated Assessment on Hypoxia in the Gulf of Mexico. NOAA Coastal Ocean Program Decision Analysis Series No. 17. NOAA Coastal Ocean Program, Silver Spring, MD, USA. 137pp. Website: http:/ /www.nos.noaa.gov/products/pubs hypox.html. (Accessed 11 August 2005).

Gordon, E.S. and Goni, M.A., 2003. Sources and distribution of terrigenous organic matter delivered by the Atchafalaya River to sediments in the northern Gulf of Mexico. Geochim. Cosmochim. Acta, 67, 2359--2375.

Govoni, J.J. and Grimes, C.B., 1992. The surface accumulation of larval fishes by hydrodynamic convergence within the Mississippi River plume front. Cont. Shelf Res., 12, 1265-1276.

Greenspan, H.P., 1962. A criterion for the existence of inertial boundary layers in oceanic circulation. Proc. Natl. Acad. Sci. U.S.A., 48, 2034-2039.

Griffin, G.M., 1962. Regional clay-mineral facies - products of weathering intensity and current distribution in the northeastern Gulf of Mexico. Geol. Soc. Amer. Bull., 73, 737-768.

Grimes, C.B., 2001. Fishery production and the Mississippi River discharge. Fisheries, 26, 17-26.

Gulf of Mexico Program, 1996a. Hypoxia conference serves as catalyst for action. Gulfwatch, 7, 1,3.

Gulf of Mexico Program, 1996b. Iowa farmers hear about Gulf hypoxia. Gulfwatch, 7, 1-2.

Gulf of Mexico Program, 1996c. Hypoxia proves complex, controversial. Gulfwatch, 7, 3.

Gunter, G., 1949. A Summary of Production Statistics and Facts Related to Development of the Oyster Industry of Louisiana, with a Brief Comparison with other Gulf States. Texas A. \& M. Research Foundation Publication No. 2. Texas A\&M University, College Station, TX, USA. 28pp.

Gunter, G., 1952. Historical changes in the Mississippi River and the adjacent marine environment. Publ. Inst. Marine Sci., (Univ. Texas, Inst. Marine Sci.) 2, 119-139.

Gunter, G., 1982. Estuarine habitat. In: The Encyclopedia of Earth Sciences, Vol. 15: The Encyclopedia of Beaches and Coastal Environments, M.L. Schwartz (Ed.), Hutchinson Ross Publishing Company, Stroudsburg, PA, USA. 398-400. 
Gupta, S.B.K., Turner, R.E. and N.N. Rabalais, N.N., 1996. Seasonal oxygen depletion in continental-shelf waters of Louisiana: Historical record of benthic foraminifers. Geology, 24, 227-230.

Hallam, A., 1967. The depth significance of shales with bituminous laminae. Mar. Geol., 5, 481-493.

Halper, F.B., McGrail, D.W. and Merrellm, W.J., Jr., 1988. Seasonal variability in the currents on the outer Texas-Louisiana shelf. Estuarine Coastal Shelf Sci., 26,33-50.

Hamilton, P. and Berger, T.J., 2002. On the structure and motion of cyclones in the northern Gulf of Mexico. J. Geophys. Res., 107, Article No. 3208. 18pp.

Happ, G., Gosselink, J.G. and Day, J.W., Jr., 1977. The seasonal distribution of organic carbon in a Louisiana estuary. Estuar. Coast. Mar. Sci. 5, 695-705.

Harper, D.E., Jr., McKinney, L.D., Salzer, R.R. and Case, R.J., 1981. The occurrence of hypoxic bottom water off the upper Texas coast and its effects on the benthic biota. Contrib. Mar. Sci., 24, 53-79.

Hatch, J.R. and Leventhal, J.S., 1992. Relationship between inferred redox potential of the depositional environment and geochemistry of the Upper Pennsylvanian (Missourian) Stark shale member of the Dennis limestone, Wabaunsee County, Kansas, U.S.A. Chem. Geol., 99, 65-82.

Hay, W.W., 1995. Paleooceanography of marine-organic-carbonrich sediments. In: Paleography, Paleoclimate, and Source Rocks, A.-Y. Huc (Ed.). AAPG Studies in Geology No. 40. American Association of Petroleum Geologists, Tulsa, OK, USA. 21-59.

He, R. and Weisberg, R.H., 2002. West Florida shelf circulation and temperature budget for the 1999 spring transition. Cont. Shelf Res., 22, 719-748.

Heckel, P.H., 1991. Thin widespread Pennsylvanian black shales of Midcontinental North America: a record of a cyclic succession of widespread pycnoclines in a fluctuating epeiric sea. In: Modern and Ancient Continental Shelf Anoxia, R.V. Tyson and T.H. Pearson (Eds.). Geological Society Special Publication No. 58, The Geological Society, London, UK. 259-273.

Hickel, W., Bauerfeind, E., Niermann, U. and Westernhagen, H.V., 1989. Oxygen deficiency in the south-eastern North Sea: sources and biological effects. Ber. Biol. Anst. Helgoland, 4, 1-148.

Hilgard, E.W., 1906. The exceptional nature and genesis of the Mississippi delta. Science, 24, 861-866.

Hitchcock, G.L., Wiseman, W.J., Jr., Boicourt, W.C., Mariano, A.J., Walker, N., Nelson, T.A. and Ryan, E., 1997. Property fields in an effluent plume of the Mississippi River. J. Mar. Syst., 12, 109-126.

Hitchcock, G.L., Chen, R.F., Gardner, G.B. and Wiseman, W.J., Jr., 2004. A Lagrangian view of fluorscent chromophoric dissolved organic matter distributions in the Mississippi River plume. Mar. Chem., 89, 225-239.

Ho, C.L. and Barrett, B.B., 1977. Distribution of nutrients in Louisiana's coastal waters influenced by the Mississippi River. Estuarine and Coastal Mar. Sci. 5, 173-195.

Hoffman, D.L., Algeo, T.J., Maynard, J.B., Joachimiski, M.M., Hower, J.C. and Jaminski, J., 1998. Regional and stratigraphic variation in bottomwater anoxia in offshore core shales of Upper Pennsylvanian cyclotherms from the Eastern Midcontinent Shelf (Kansas), U.S.A. In: Shales and Mudstones. Volume 1. Basin Studies, Sedimentology, and Paleontology, J. Schieber, W. Zimmerle, and P.S. Sethi (Eds.). E. Schweizerbart'sche Verlagsbuchhandlung (Naglele u. Obermiller), Stuttgart, Germany. 243-269.

Holmden, C., Creaser, R.A., Muehlenbachs, K., Leslie, S.A. and Bergstrom, S.M., 1998. Isotope evidence for geochemical decoupling between ancient epeiric seas and bordering oceans: implications for secular curves. Geology, 26, 567-570.
Hu, C., Muller-Karger, F.E., Biggs, D.C., Carder, K.L., Nababan, B., Nadeau, D. and Vanderbloemen, J., 2003. Comparison of ship and satellite bio-optical measurements on the continental margin of the NE Gulf of Mexico. Int. J. Remote Sens., 24, 2597-2612.

Huang, T-C. and Goodell, H.G., 1970. Sediments and sedimentary processes of eastern Mississippi cone, Gulf of Mexico. Amer. Assoc. Petrol. Geol. Bull., 54, 2070-2100.

Huh, O.K., Walker, N.D. and Moeller, C., 2001. Sedimentation along the eastern Chenier Plain coast: down drift impact of a delta shift complex. J. Coast. Res., 17, 72-81.

Humphreys, A.A. and Abbot, H.L., 1876 (revised). Report Upon the Physics and Hydraulics of the Mississippi River. U.S. Government Printing Office, Washington, DC, USA. 691pp.

Hunter, E.J., 2001. Advection transport on the Louisiana-Texas shelf. M.Sc. Thesis, University of Delaware, Newark, DL, USA. $72 \mathrm{pp}$.

Ichiye, T., 1960. On the hydrography near the Mississippi delta. Oceanogr. Mag., 11, 65-78.

Isaksen, G.H., 1995. Organic geochemistry of paleodepositional environments with a predominance of terrigenous higher-plant organic matter. In: Paleography, Paleoclimate, and Source Rocks, A.-Y. Huc (Ed.). AAPG Studies in Geology No. 40. American Association of Petroleum Geologists, Tulsa, OK, USA. 81-104.

Jackson, L.L., Foote, A.L. and Balistrieri, L.S., 1995. Hydrological, geomorphological, and chemical effects of Hurricane Andrew on coastal marshes of Louisiana. J. Coastal Res. Special Issue 21, 306-323.

Jenkyns, H.C., 1980. Cretaceous anoxia events: from continents to oceans. J. Geol. Soc., 137, 171-188.

Jonasson, P.M. and Lindegaard C., 1979. Zoobenthos and its contribution to the metabolism of shallow lakes. Arch. Hydrobiol. Beih. Ergebn. Limnol., 13, 162-180.

Jones, J.I. and Williams, S.E., 1979. The distribution and origin of bottom sediments in Timbalier Bay, Louisiana, and the adjacent offshore area. Rice University Studies, 65, 201-221.

Justic, D., Rabalais, N.N. and Turner, R.E., 1997. Impacts of climate change on net productivity of coastal waters: implications for carbon budgets and hypoxia. Climate Res., 8 , 225-237.

Justic, D., Rabalais, N.N. and Turner, R.E., 2003a. Simulated responses of the Gulf of Mexico hypoxia to variations in climate and anthropogenic nutrient loading. J. Mar. Syst., 42, 115-125.

Justic, D., Turner, R.E. and Rabalais, N.N., 2003b. Climatic influences on riverine nitrate flux: implications for coastal marine eutrophication and hypoxia. Estuaries, 26, 1-11.

Justic, D., Rabalais, N.N. and Turner, R.E., 2005. Coupling between climate variability and coastal eutrophication: evidence and outlook for the northern Gulf of Mexico. J. Sea. Res., 54, $25-35$.

Kelly, V.J., Hooper, R.P., Aulenbach, B.T. and Janet, M., 2001. Concentrations and annual fluxes for selected water-quality constituents from the USGS National Stream Quality Accounting Network (NASQAN), 1996-2000. U.S. Geological Survey Water-Resources Investigations Report 01-4255. various paging Website: http://purl.access.gpo.gov/GPO/LPS23098 (Accessed 11 August 2005).

Kemp, G.P., Suhayda, J.N., Mashriqui, H.S., van Heerden, I.L. and Malbrough, O., 1995. Development of a Long-Term Water and Sediment Distribution Plan for the Lower Atchafalaya Basin to Minimize Flooding to Local Communities and to Determine the Impacts of the Present Wax Lake Outlet Weir: Phase 1, Task 2. Assessment of the Impact of the Wax Outlet Weir on the Water Levels and Sedimentation within the Lower Atchafalaya River. Report to the Mayors of Morgan/Berwick, LA, USA. 50pp. plus 3 appendices. 
Kesel, R.H., 1988. The decline in the suspended load of the lower Mississippi River and its influence on adjacent wetlands. Environ. Geol. Water Sci., 11, 271-281.

Khromov, N.S., [1965] 1969. Distribution of plankton in the Caribbean Sea. In: A.S. Bogdanov (ed.). Soviet-Cuban Fishery Research. Israel Program for Scientific Translations, Jerusalem, Israel. Translated from Sovetsko-Kubinskie rybokhozyaistvennye issledovaniya, Izdatel'stvo "Pishchevaya Promyshlennost", Moskva 1965. 36-56.

Kosters, E.C. and Suter, J.R., 1993. Facies relationships and system tracts in the Late Holocene Mississippi Delta Plain. J. Sed. Petrol., 63, 727-733.

Kosters, E.C., Jorissen, F.J., Van der Zwaan, G.J. and Suter, J.R., 2002. Predicting deltaic rock sources using sequence stratigraphy. In: AAPG Annual Meeting, March 10-13, 2002, Houston, Texas, George R. Brown Convention Center, With SEMP (Society for Sedimentary Geology). American Association for Petroleum Geologists, Tulsa, OK, USA. 96.

Kosters, E.C., Van der Zwaan, G.J. and Jorissen, F.J., 2000. Production, preservation and prediction of source-rock facies in deltaic settings. Int. J. Coal Geol., 43, 13-26.

Krug, E.C., 2007. Coastal change and hypoxia in the northern Gulf of Mexico. Hydrol. Earth Syst. Sci., 11, 180-190.

Krug, E.C. and Merrifield, K., 2006. Satellite imagery of the hypoxic zone in the northern Gulf of Mexico. Website: http:// www.sws.uiuc.edu/

Kutkuhn, J.H., 1963. Expanded research on Gulf of Mexico shrimp resources. Proc. Gulf and Caribbean Fisheries Institute, $15^{\text {th }}$ Annual Session 1962. 65-78.

La Banc, R.J., Sr. and Steffens, G.S., 1986. Early studies of the Mississippi entrenched valley/submarine canyon system. Amer. Ass. Petrol. Geol. Bull., 70, 11184-1185.

Leckie, D.A., Singh, C., Goodarzi, F. and Wall, J.H., 1990. Organic-rich, radioactive marine shale: a case study of a shallowwater condensed section, Cretaceous Shaftesbury Formation, Alberta, Canada. J. Sed. Petrol., 60, 101-117.

Lee, H-C and Mellor, G.L., 2003. Numerical simulation of the Gulf Stream system: the Loop Current and the deep circulation. J. Geophys. Res., 108(C2), 3043, doi:10.1029/2001JC001074.

Levin, D.R., 1991. Transgressions and regressions in the Barataria Bight region of coastal Louisiana. Trans. Gulf Coast Assoc. Geol. Soc., 41, 408-435.

Levin, D.R., 1993. Tidal inlet evolution in the Mississippi River delta plain. J. Coastal Res., 9, 462-480.

Li, Y, Nowlin, W.D., Jr. and Reid, R.O., 1996. Spatial-scale analysis of hydrographic data over the Texas-Louisiana continental shelf. J. Geophys. Res., 101, 20,595-20,605.

Li, Y, Nowlin, W.D., Jr. and Reid, R.O., 1997. Mean hydrographic fields and their interannual variability over the Texas-Louisiana continental shelf in spring, summer, and fall. J. Geophys. Res., 102, 1027-1049.

Liebman, E., 1940. River discharges and their effect on the cycles and productivity of the sea. Proceedings of the Sixth Pacific Science Congress of the Pacific Science Association. Held at the University of California, Berkeley, Stanford University, and San Francisco, July $24^{\text {th }}$ to August $12^{\text {th }}, 1939$. University of California Press, Berkeley. 517-523.

Lindsay, J.F., Prior, D.B. and Coleman, J.M., 1984. Distributarymouth bar development and role of submarine landslides in delta growth, South Pass, Mississippi delta. Amer. Assoc. Petrol. Geol. Bull., 68, 1732-1743.

Linton, T.L., 1968. A description of the South Atlantic and Gulf Coast marshes and estuaries. In: Proce. Marsh and Estuary Management Symposium, Louisiana State University, Baton Rouge, Louisiana, July 19-20, 1967, J.D. Newsom (Ed.). Louisiana State University, Baton Rouge, LA, USA. 15-25.
List, J.H., Jaffe, B.E., Sallenger, A.H., Jr., Williams, S.J., McBride, R.A. and Penland, S., 1994. Louisiana Barrier Island Erosion Study: Atlas of Sea-floor Changes from 1878 to 1989. U.S. Geol. Surv. Misc. Invest. Ser. I-2150-B. U.S. Geological Survey, Reston, VA, USA. 81pp.

Loesch, H., 1960. Sporadic mass shoreward migrations of demersal fish and crustaceans in Mobile Bay, Alabama. Ecology, 41, 292298.

Lohrenz, S.E., Dagg, M.J. and Whitledge, T.E., 1990. Enhanced promary productivity at the plume/oceanic interface of the Mississippi River. Continental Shelf Res., 7, 639-664.

Lohrenz, S.E., Fehnentiel, G.L., Redalje, D.G., Lang, G.A., Chen, X. And Dagg, M.J., 1997. Variations in primary production of northern Gulf of Mexico continental shelf waters linked to nutrient inputs from the Mississippi River. Mar. Ecol. Prog. Ser., 155, 45-54.

Lohrenz, S.E., Fehnentiel, G.L., Redalje, D.G., Lang, G.A., Dagg, M.J., Whitledge, T.E. and Dortch, Q., 1999. Nutrients, irradiance, and mixing as factors regulating primary production in coastal waters impacted by the Mississippi River plume. Continental Shelf Res., 19, 1113-1141.

Lopez-Veneroni, D.G., 1998. The dynamics of dissolved and partivulate nitrogen in the northwest Gulf of Mexico. Ph.D. Thesis, Texas A \& M University, College Station, TX,USA. 256pp.

Lopez-Veneroni, D. and Cifuentes, L.A., 1994. Transport of dissolved organic nitrogen in Mississippi River plume and Texas-Louisiana continental shelf near-surface water. Estuaries, 17, 796-808.

Louisiana Coastal Wetlands Conservation and Restoration Task Force and the Wetlands Conservation and Restoration Authority, 1998. Coast 2050: Toward A Sustainable Coastal Louisiana. Louisiana Department of Natural Resources, Baton Rouge, LA, USA. 161pp. Website: http://www.lacoast.gov/Programs/2050/ MainReport/report1.pdf. (Accessed 11 August 2005).

Louisiana Universities Marine Consortium, 2001. Press release issued on July 26, 2001 by Louisiana Universities Marine Consortium (LUMCOM). Website: http://www.epa.gov/ msbasin/pressrelease.htm (Accessed 15 December 2004).

Louisiana Universities Marine Consortium, 2002. Summer 2002 hypoxia. LUMCON Press Release, July 26, 2002. Louisiana Universities Marine Consortium, Chauvin, LA, USA. Website: http://www.lumcon.edu/Information/news/ default.asp?year=2002 (Accessed 11 August 2005).

Louisiana Universities Marine Consortium, 2003. Tropical storms put the oxygen back into the 'dead zone.' LUMCON Press Release, July 29, 2003. Louisiana Universities Marine Consortium, Chauvin, LA, USA. Website: http:// www.lumcon.edu/Information/news/default.asp?year $=2003$ (Accessed 11 August 2005).

Louisiana Universities Marine Consortium, 2004. Average size 'dead zone' in anything but an average year. LUMCON Press Release, July 26, 2004. Louisiana Universities Marine Consortium, Chauvin, LA, USA. Website: http:// www.lumcon.edu/Information/news/ (Accessed 11 August 2005).

Louisiana Universities Marine Consortium, 2005. Mapping of dead zone completed. LUMCON Press Release, July 29, 2005 Louisiana Universities Marine Consortium, 2004. Average size 'dead zone.' in anything but an average year. LUMCON Press Release, July 26, 2004. Louisiana Universities Marine Consortium, Chauvin, LA, USA. Website: http:// www.lumcon.edu/Information/news/ (Accessed 11 August 2005).

Lowman, S.W., 1951. The relationship of the biotic and lithic facies in Recent Gulf Coast sedimentation. J. Sed. Petrology, 21, 233237. 
Ludwig, W., Probst, J-L and Kempe, S., 1996. Predicting the oceanic input of organic carbon by continental erosion. Global Biogeochem. Cycles, 10, 23-41.

Lugo-Fernandez, A., 1998. Ecological implications of hydrography and circulation to the Flower Garden Banks, northwest Gulf of Mexico. Gulf of Mexico Science, 16, 144-160.

Lugo-Fernandez, A., Morin, M.V., Ebesmeyer, C.C. and Marshall, C.F., 2001. Gulf of Mexico historic (1955-1987) surface drifter data analysis. J. Coast. Res., 17, 1-16.

Lyell, C., 1849. A Second Visit to the United States of North America. Volume II. John Murray, London, England. 385pp.

Lynch, S.A., 1954. Geology of the Gulf of Mexico. In: Gulf of Mexico: Its Origin, Waters, and Marine Life, P.S. Galtsoff(Ed.) U.S. Fish and Wildlife Service Fishery Bulletin 89, Volume 55. U.S. Government Printing Office, Washington, DC, USA. 3986.

Mackin, J.G. and Hopkins, S.H., 1961. Studies on oyster mortality in relation to natural environments and to oil fields in Louisiana. Publ. Inst. Mar. Sci., Univ. Texas, 7, 1-131.

Madden, C.J., Day, J.W., Jr. and Randall, J.M., 1988. Freshwater and marine coupling of the Mississippi River deltaic plain. Limnol. Oceanogr., 33, 982-1004.

Malcolm, R.L. and Durham, W.H., 1976. Organic carbon and nitrogen concentrations and annual organic load of six selected rivers of the United States. U.S. Geological Survey Water-Supply Paper 1817-F. 21pp.

Martens, C.S., Berner, R.A. and Rosenfeld, J.K., 1978. Interstitial water chemistry of anoxia in Long Island Sound sediments. 2. Nutrient regeneration and phosphate removal. Limnol. Oceanogr., 23, 605-617.

Martin, J.F., White, M.L., Reyes, E., Kemp, G.P., Mashrique, H. and J.W. Day, Jr., 2000. Evaluation of coastal management plans with a spatial model: Mississippi delta, LA, USA. Environ. Manage., 26, 117-129.

Martinez-Lopez, B. and Pares-Sierra, A., 1998. Circulation in the Gulf of Mexico induced by tides, wind and the Yucatan Current. Ciencias Marinas, 24, 65-93.

Maul, G., 1974. An Evaluation of the Use of the Earth Resources Technology Satellite for Observing Ocean Current Boundaries. $\mathrm{Ph} . \mathrm{D}$. thesis. University of Miami, Coral Gables, FL, USA. $125 \mathrm{pp}$.

Maul, G.A., 1977. The annual cycle of the Gulf Loop Current, Part I: Observations during a one-year time series. J. Mar. Res., 35, 29-47.

May, E.B., 1973. Extensive oxygen depletion in Mobile Bay, Alabama. Limnol. Oceanogr., 18, 353-366.

Mayer, L.M., Keil, R.G., Macko, S.A. Joye, S.B., Ruttenberg, K.C. and Aller, R.C., 1998. Importance of suspended particulates in riverine delivery of bioavailable nitrogen to coastal zones. Global Biogeochemical Cycles 12, 573-579.

McBrayer, M.C., 2004. The River War: the Mississippi vs. the Atchafalaya. University of Texas, Austin, TX, USA. 18pp. Website: http://civilu.ce.utexas.edu/stu/mcbraymc/ ce385proposal.html. (Accessed 11 August 2005).

McKee, B.A., Aller, R.C., Allison, M.A., Bianchi, T.S. and Kineke, G.C., 2004. Transport and transformation of dissolved and particulate materials on continental margins influenced by major rivers: benthic boundary layer and seabed processes. Cont. Shelf Res., 24, 899-926.

McLellan, H.J., 1965. Elements of Physical Oceanography. Pergamon Press, Oxford, UK. 150pp.

McPhee, J., 1989. The Control of Nature. Farrar, Straus and Giroux, New York, New York, USA. 272pp.

Meade, R.H. 1995. Setting: Geology, hydrology, sediments, and engineering of the Mississippi River. Contaminants in the Mississippi River. R. H. Meade (Ed.). U.S. Geological Survey
Circ. No. 1133. U.S. Geological Survey, Reston, VA, USA. 1330.

Mello, M.R., Telnaes, N. and Maxwell, J.R., 1995. The hydrocarbon source potential in the Brazilian marginal basins: a geochemical and paleoenvironmental assessment. In: Paleography, Paleoclimate, and Source Rocks, A.-Y. Huc (Ed.). AAPG Studies in Geology No. 40. American Association of Petroleum Geologists, Tulsa, OK, USA. 233-272.

Mississippi River/Gulf of Mexico Watershed Nutrient Task Force, 1997. First Meeting Summary First Meeting of the Mississippi River/Gulf of Mexico Watershed Nutrient Task Force, Key Bridge Marriott, Arlington, Virginia, USA. Website: http:// www.epa.gov $/ \mathrm{msbasin} /$ taskforce/summaries/1stsummary.htm (Accessed 19 September 2005).

Mississippi River/Gulf of Mexico Watershed Nutrient Task Force, 2001. Action Plan for Reducing, Mitigating, and Controlling Hypoxia in the Northern Gulf of Mexico. US Environmental Protection Agency, Washington, DC. 31pp. Website: http:// www.epa.gov/owow/msbasin/taskforce/actionplan.htm (Accessed 11 August 2005).

Mississippi River/Gulf of Mexico Watershed Nutrient Task Force, 2003. Tenth Meeting of the Mississippi River/Gulf of Mexico Watershed Nutrient Task Force, Renaissance Hotel, St. Louis, Missouri, November 19, 2003. Website: http://www.epa.gov/ msbasin/taskforce/summaries/10thMeetSumm.pdf(Accessed 19 September 2005).

Mitsch, W.J., Day, J.W., Jr., Gilliam, J.W., Groffman, P.M., Hey, D.L., Randall, G.W. and Wang, N., 1999. Reducing Nutrient Loads, Especially Nitrate - Nitrogen, to Surface Water, Ground Water, and the Gulf of Mexico. Topic 5 Report for the Integrated Assessment on Hypoxia in the Gulf of Mexico. NOAA Coastal Ocean Program Decision Analysis Series No. 19. NOAA Coastal Ocean Program, Silver Spring, MD, USA. 111pp. Website: http:/ /www.nos.noaa.gov/products/pubs hypox.html. (Accessed 11 August 2005).

Morey, S.L., Martin, P.J., O'Brien, J.J., Wallcraft, A.A. and ZavalaHidalgo, J., 2003a. Export pathways for river discharged fresh water in the northern Gulf of Mexico. J. Geophys. Res., 108(C10), 3303, doi:1029/2002JC001674.

Morey, S.L., Schroeder, W.W., O'Brien, J.J. and Zavala-Hidalgo, J., 2003b. The annual cycle of riverine influence in the eastern Gulf of Mexico basin. Geophys. Res. Lett., 30, 1867, doi:10.1029/2003GL017348.

Morgan, D.J., 1977. The Mississippi River Delta: LegalGeomorphological Evaluation of Historic Shoreline Changes. Geoscience and Man Volume 16. Louisiana State University, Baton Rouge, LA, USA. 196pp. plus four maps.

Morgan, J.P., 1979. Recent geological history of the Timbalier Bay area and adjacent continental shelf. Rice University Studies, 65, 575-589.

Morgan, J.P. and Larimore, P.B., 1957. Changes in the Louisiana shoreline. Trans. Gulf Coast Assoc. Geol. Soc., 7, 303-310.

Morgan, J.P., Nichols, L.G. and Wright, M., 1958. Morphological effects of Hurricane Audrey on the Louisiana coast. Louisiana State University Coastal Studies Institute Technical Report No. 10., Part A. Louisiana State University, Baton Rouge, LA, USA. $53 \mathrm{pp}$.

Mossa, J., 1989. Hysteresis and nonlinearity of sediment-discharge relationships in the Atchafalaya and lower Mississippi rivers. IAHS Publication No. 184, 105-112.

Mossa, J., 1991. Temporal and downstream changes in suspended sediment transport in the Atchafalaya and Mississippi rivers, Louisiana. In: Coastal Depositional Systems in the Gulf of Mexico: Ouaternary Framework and Environmental issues. Twelfth Annual research Conference, GulfCoast Section, Society of Economic Paleontologists and Mineralogists Foundation. 
Adams mark Hotel, Houston, Texas, December 8-11, 1991. Gulf Coast Section, Society of Economic Paleontologists and Mineralogists Foundation. Distributed by Earth Enterprises, Inc., Austin, TX, USA. 159-163.

Moum, J.N., Farmer, D.M., Smyth, W.D., Armi, L. and Vagle, S., 2003. Structure and generation of turbulence at interfaces strained by internal solitary waves propagating over the continental shelf. J. Phys. Ocean., 33, 2093-2112.

Muller-Karger, F.E., 2000. The spring 1998 northeastern Gulf of Mexico (NEGOM) cold water event: remote sensing evidence for upwelling and for eastward advection of Mississippi water. Gulf of Mexico Sci., 18, 55-67.

Muller-Karger, F.E., Walsh, J.J., Evans, R.H. and Meyers, M.B., 1991. On the seasonal phytoplankton concentration and sea surface temperature cycles of the Gulf of Mexico as determined by satellites. J. Geophys. Res., 96, 12,645-12,665.

Murray, S.P., 1976. Currents and Circulation in the Coastal Waters of Louisiana. Sea Grant Publication No. LSU-T-76-003. Center for Wetland resources, Baton Rouge, LA, USA. 35pp.

Nash, J.D. and Moum, J.N., 2005. River plumes as a source of large-amplitude internal waves in the coastal ocean. Nature, 437, 400-403.

National Centers for Coastal Ocean Science, 2004. Scientists work for a better understanding of the causes and cures of hypoxia in the Gulf of Mexico. National Centers for Coastal Ocean Science, NOAA, USA. Website: http://www/nccos.noaa.gov/ news/aug02.html (Accessed 29 December 2004).

National Hurricane Center, 2006. NHC/TPC archive of hurricane seasons. National Hurricane Center, National Weather Service, NOAA, USA. Website: www.nhc.noaa.gov/pastall.shtml (Accessed 21 March 2006)

National Ocean Service, 1985. Gulf of Mexico: Coastal and Ocean Zones Strategic Assessment: Data Atlas. United States Government Printing Office, Washington, DC, USA. 179pp.

National Oceanic and Atmospheric Administration (NOAA), 1997. NOAA's Estuarine Eutrophication Survey, Volume 4: Gulf of Mexico Region. NOAA Office of Ocean Resources Conservation and Assessment, Silver Spring, MD, USA. 77pp.

National Research Council, 1983. Drilling Discharges in the Marine Environment. National Academy Press, Washington, DC, USA. 180pp.

Nelson, C.H., 2002. Basic types of turbidite systems based on modern sea floor images. Amer. Assoc. Petrol. Geol. Bull. 86(13) Supplement.

Nelson, C.H., Damuth, J.E., Olson H.C., and Twitchell, D., 2002. Comparison of modern mini-basins to deep-sea fan turbidite systems in the Gulf of Mexico. Amer. Assoc. Petrol. Geol. Bull. 86(13) Supplement.

Nelsen, T.A., Blackwelder, P., Hood, T., McKee, B., Romer, N, Alvarez-Zarikian, C. and Metz, S., 1994. Time-based correlation of biogenic, lithogenic, and authigenic sediment components with anthropogenic inputs in the Gulf of Mexico NECOP study area. Estuaries, 17, 873-885.

Nerem, R.S., van Dam, T.M. and Schenewerk, M.S., 1998. Chesapeake Bay subsidence monitored as wetland loss continues. EOS, Trans. Amer. Geophys. Union, 79, 149, 156-157.

Ocean Remote Sensing Group, 2006. Ocean remote sensing. Ocean Remote Sensing Group, John Hopkins University Applied Physics laboratory, USA. Website: http://fermi.jhuapl.edu/hurr (Accessed 21 March 2006).

Odum, E.P., 1971. Fundamentals of Ecology. $3^{\text {rd }}$ Edition. W.B. Saunders Company, Philadelphia, Pennsylvania, USA. 574pp.

Odum, E.P., 2000. Tidal marshes as outwelling/pulsing systems. In: Concepts and Controversies in Tidal Marsh Ecology, M.P. Weinstein and D.A. Kreeger (Eds.). Kluwer Academic Publishers, Dordrecht, The Netherlands. 3-7.
Oetking, P., Back, R, Watson, R. and Merks, C., 1979a. Physical studies of the near-shore continental shelf of south central Louisiana: currents and hydrography. Rice University Studies, 65, 119-143.

Oetking, P., Back, R, Watson, R. and Merks, C., 1979b. Surface and shallow subsurface sediments of the near-shore continental shelf of south central Louisiana. Rice University Studies, 65, 181-200.

Oey, L.Y., 1995. Eddy- and wind-forced shelf circulation. $J$. Geophys. Res., 100, 8621-8637.

Ohlmann, J.C., Niiler, P.P., Fox, C.A. and Leben, R.R., 2001. Eddy energy and shelf interaction in the Gulf of Mexico. J. Geophys. Res., 106, 2605-2620.

Olszewski, T., 1996. Sequence stratigraphy of an upper Pennsylvanian, midcontinent cyclotherm from North America (Iola limestone, Kansas and Missouri, USA). Facies, 35, 81103.

Ortner, P.B., Ferguson, R.L., Piotrowicz, S.R., Chesal, L., Berberian, G. and Palumbo, A.V., 1984. Biological consequences of hydrographic and atmospheric advection within the Gulf Loop Intrusion. Deep Sea Res., 31, 1101-1120.

Ortner, P.B., Lee, T.N., Zika, P.J., Clarke, M.E., Podesta, G.P., Swart, P.K., Tester, P.A., Atkinson, L.P. and Johnson, W.R., 1995. Mississippi River flood waters that reached the Gulf Stream. J. Geophys. Res., 100, 13595-13601.

Oschmann, W., 1991. Distribution, dynamics and palaeoecology of Kimmeridgian (Upper Jurassic) shelf anoxia in western Europe. In: Modern and Ancient Continental Shelf Anoxia, R.V. Tyson and T.H. Pearson (Eds.). Geological Society Special Publication No. 58, The Geological Society, London, UK. 381395.

Osterman, L.E., Poore, R.Z., Swarzenski, P.W. and Turner, R.E., 2005. Reconstructing a $180 \mathrm{yr}$ record of natural and anthropogenic induced low-oxygen conditions from Louisiana continental shelf sediments. Geology, 33, 329-332.

Otvos, E.G. and Price, W.A., 1982. Chenier and chenier plain. In: The Encyclopedia of Beaches and Coastal Environments, M.L. Schwartz (Ed.). Encyclopedia of Earth Sciences:Volume 15. Hutchinson Ross Publishing Co., Stroudsburg, PA, USA. 206207.

Paul, J.H., Alfreider, A., Kang, J.B., Stokes, R.A., Griffin, D., Campbell, L. and Ornolfsdottir, E., 2000a. Form IA $r b c L$ transcripts associated with a low salinity/high chlorophyll plume ('Green River') in the eastern Gulf of Mexico. Mar. Ecol. Prog. Ser., 198, 1-8.

Paul, J.H., Alfreider, A. and Wawrik, B., 2000b. Micro- and macrodiversity in $r b c L$ sequences in ambient phytoplankton populations from the southeastern Gulf of Mexico. Mar. Ecol. Prog. Ser., 198, 9-18.

Penland, S. and Boyd, R., 1985. Mississippi delta and barrier shoreline development. In: Transgressive Depositional Environments of the Mississippi River Delta Plain: A Guide to Barrier Islands, Beaches and Shoals in Louisiana, S. Penland and R. Boyd (Eds.). Louisiana Geological Survey, Baton Rouge, LA, USA. 53-122.

Pepper, D.A., Stone, G.W. and Wang, P., 1999. Bottom boundary layer parameters and sediment transport on the Louisiana innershelf during cold front passages. Trans. Gulf Coast Assoc. Geol. Soc., 49, 409-416.

Perret, W.S. and Chatry, M.F., 1988. The Louisiana oyster fishery: industry and management confront a changing environment. $J$. Shellfish Res., 7, 303-307.

Pickard, G.L., 1979. Descriptive oceanography: an introduction. Third Edition (in SI Units). Pergamon Press, Oxford, UK. 233pp. 
Picou, E.B., Jr., 1981. McAllen Ranch field: depositional environments of reservoir sandstones and associated shales the Shell Oil Company viewpoint. In: Recognition of ShallowWater Versus Deep-Water Sedimentary Facies in GrowthStructure Affected Formations of the Gulf Coast Basin. Second Annual Research Conference, Gulf Coast Section, Society of Economic Paleontologists and Mineralogists. Program and Abstracts. Marriot Hotel Market Center, Dallas, Texas, November 29 - December 2, 1981. Gulf Coast Section, Society of Economic Paleontologists and Mineralogists, Austin, TX, USA. $48-51$

Pingree, R.D., Bowman, M.J.and Esaias, W.E., 1978. headland fronts. In: Oceanic fronts in coastal processes. Proc. Workshop at Marine Sciences Research Center, May 25-27, 1977, M.J. Bowman and W.E. Esaias (Eds.), Springer-Verlag, Berlin, Germany. 78-86.

Platon, E., Sen Gupta, B.K., Rabalais, N.N. and Turner, R.E., 2005. Effect of seasonal hypoxia on the benthic foraminiferal community of the Louisiana inner continental shelf: the $20^{\text {th }}$ century record. Mar. Micropaleon., 54, 263-283.

Pokryfki, L. and Randall, R.E., 1987. Nearshore hypoxia in the bottom water of the northwestern Gulf of Mexico from 1981 to 1984. Mar. Environ. Res., 22, 75-90.

Pratt, L.M., 1984. Influence of paleoenvironmental factors on preservation of organic matter in middle Cretaceous Greenhorn Formations, Pueblo, Colorado. Amer. Assoc. Petrol. Geol. Bull., 68, 1146-1159.

Rabalais, N.N., Turner, R.E. and Wiseman, W.J., Jr., 1997. The hypoxic zone in the Gulf of Mexico. Paper presented at American Farm Bureau Federation, July 14-15,1997, St. Louis, MO, USA. $15 \mathrm{pp}$.

Rabalais, N.N., Turner, R.E. and Scavia, D., 2002a. Beyond science into policy: Gulf of Mexico hypoxia and the Mississippi River. BioScience, 52, 129-142.

Rabalais, N.N., Turner, R.E. and Wiseman, W.J., Jr., 2002b. Gulf of Mexico hypoxia, a.k.a. "the Dead Zone." Annu. Rev. Ecol. Syst., 33, 235-263.

Rabalais, N.N., Turner, R.E., Wiseman, W.J., Jr. and Boesch, D.F., 1991. A brief summary of hypoxia on the northern Gulf of Mexico continental shelf: 1985-1988. In: Modern and Ancient Continental Shelf Anoxia, R.V. Tyson and T.H. Pearson (Eds.). Geological Society Special Publication No. 58. The Geological Society, London, UK. 35-47.

Rabalais, N.N., Atilla, N., Normandeau, C. and Turner, R.E., 2004. Ecosystem history of the Mississippi River-influenced continental shelf revealed through preserved phytoplankton pigments. Mar. Pollut. Bull., 49, 537-547.

Rabalais, N.N., Turner, R.E., Justic, D., Dortch, Q. and Wiseman, W.J., Jr., 1999. Characterization of Hypoxia. Topic 1 Report for the Integrated Assessment on Hypoxia in the Gulf of Mexico. NOAA Coastal Ocean Program Decision Analysis Series No. 15. NOAA Coastal Ocean Program, Silver Spring, MD, USA. 185pp. Website: http://www.nos.noaa.gov/products/ pubs hypox.html. (Accessed 11 August 2005).

Rabalais, N.N., Turner, R.E., Justic, D., Dortch, Q., Wiseman, W.J., Jr. and Gupta, B.K.S., 1996. Nutrient changes in the Mississippi River and system responses on the adjacent continental shelf. Estuaries, 19B, 386-407.

Ragan, J.G., Harris, A.H. and Green, J.H., 1978. Temperature, salinity and oxygen measurements of surface and bottom waters on the continental shelf off Louisiana during portions of 1975 and 1976. 2.:Professional Papers Series (Biology) Number Three. Nicholls State University, Thibodaux, LA, USA. 29pp.

Rainwater, E.H., 1972. The factors which control petroleum accumulations. Trans. Gulf Coast Assoc. Geol. Soc., 22, 3954.
Reed, D.J., Swenson, E.M. and Gosselink, J.G., 1995. Part 2: physical setting. In: Status and Historical Trends of Hydrologic Modification, Reduction in Sediment Availability, and Habitat Loss/Modification in the Barataria and Terrebonne Estuarine System, Reed, D.J. (Ed.). BTNEP Publ. No. 20, BaratariaTerrebonne National Estuary Program, Thibodaux, LA, USA. 7-23.

Riddell, J.L., 1846. Deposits of the Mississippi River and changes at its mouth. Commercial Rev. South and West, 49, 433-439.

Riley, G.A., 1937. The significance of the Mississippi River drainage for biological conditions in the northern Gulf of Mexico. J. Mar. Res. 1, 60-74.

Roberts, H.H., 1994. Introduction. In: Final Report: Critical Physical Processes of Wetland Loss 1988 - 1994, H.H. Roberts (Ed.). U.S. Geological Survey, Reston Virginia, USA. 1.1-1.13.

Roberts, H.H., 1997. Dynamic changes of the Holocene Mississippi River delta plain: the delta cycle. J. Coastal Res., 13, 605-627.

Roberts, H.H., 1998. Delta switching: early responses to the Atchafalaya River diversion. J. Coastal Res., 14, 882-899.

Roberts, H.H., Adams, R.D. and Cunningham, R.H.W., 1980. Evolution of sand-dominant subaerial phase, Atchafalaya delta, Louisiana. Amer Assoc. Petrol. Geol. Bull., 64, 264-279.

Rossignol-Strick, M., 1985. A marine anoxic event on the Brittany Coast, July 1982. J. Coastal Res., 1, 11-20.

Rouse, L.J. and Coleman, J.M., 1976. Circulation observations in the Louisiana Bight using LANDSAT Imagery. Remote Sens. Environ., 5, 55-66.

Rowe, G.T., Clifford, C.H. and Smith, K.L., Jr., 1975. Benthic nutrient regeneration and its coupling to primary productivity in coastal waters. Nature, 255, 215-217.

Rowe, G.T., Kaegi, M.E.C., Morse, J.W., Boland, G.S. and Briones, E.G.E., 2002. Sediment community metabolism associated with continental shelf hypoxia, northern Gulf of Mexico. Estuaries, 25, 1097-1106.

Sahl, L.E., Merrell, W.J. and Biggs, D.C., 1993. The influence of advection on the spatial variability of nutrient concentrations on the Texas-Louisiana continental shelf. Cont. Shelf Res., 13, $233-251$

Sahl, L.E., Wiesenburg, D.A. and Merrell, W.J., 1997. Interactions of mesoscale features with Texas shelf and slope waters. Cont. Shelf Res., 17, 117-136.

Scavia, D. Untitled cover letter, December 1998. National Ocean Service, Silver Spring, Maryland, USA. 2pp.

Scavia, D., Rabalais, N.N., Turner, R.E., Justic, D. and Wiseman, W.J., Jr., 2003. Predicting the response of Gulf of Mexico hypoxia to variations in Mississippi River nitrogen load. Limnol. Oceanogr., 48, 951-956.

Schultz, R.B. and Coveney, R.M., Jr., 1992. Time-dependent changes for Midcontinent Pennsylvanian black shales, U.S.A. Chem. Geol., 99, 83-100.

Scruton, P.C., 1956. Oceanography of Mississippi delta sedimentary environments. Amer. Assoc. Petrol. Geol. Bull., 40, 2864-2952.

Scruton, P.C., 1960. Delta building and the deltaic sequence. Recent Sediments, Northeast Gulf of Mexico AAPG Symposium Volume 1960. American Association of Petroleum Geologists, Tulsa, Oklahoma, USA, 82-102.

Scruton, P.C. and Moore, D.G., 1953. Distribution of surface turbidity off Mississippi delta. Am. Assoc. Petrol. Geol. Bull. 37, 1067-1074.

Sen Gupta, B.K., Turner, R.E. and Rabalais, N.N., 1996. Seasonal oxygen depletion in continental-shelf waters of Louisiana: historical record of benthic foraminifers. Geology, 24, 227-230.

Sharp, J.M. and Appan, S.G., 1978. Cumulative effects of oil drilling and production on estuarine and near-shore ecosystems. 
In: Estuarine Interactions, M.L. Wiley (Ed.). Academic Press, New York, NY, USA. 57-73.

Shepard, F.P., 1956. Marginal sediments of Mississippi Delta. Amer. Assoc. Petrol. Geol. Bull., 40, 2537-2623.

Shlemon, R.J., 1972. o:Development of the Atchafalaya Delta, Louisiana. Hydrologic and Geologic Studies of Coastal Louisiana Report No. 13. Louisiana State University, Baton Rouge, LA, USA. 51pp.

Showstack, R., 1997. Gulf of Mexico hypoxia zone stirs policy discussions. EOS, Trans. Amer. Geophys. Union, 78, 478, 483.

Sklar, F.H. and Turner, R.E., 1981. Characteristics of phytoplankton production off Barataria Bay in an area influenced by the Mississippi River. Contrib. Mar. Sci., 24, 93106.

Smith, I.R. and Sinclair, I.J., 1972. Deep water waves in lakes. Freshwater Biol., 2, 387-399.

Smith, S.M. and Hitchcock, G.L., 1994. Nutrient enrichments and phytoplankton growth in the surface waters of the Louisiana Bight. Estuaries, 17, 740-753.

Smith, S.V. and Mackenzie, F.T., 1987. The ocean as a net heterotrophic system: implications from the carbon biogeochemical cycle. Global Biogeochem. Cycles, 1, 187-198.

Sonnenfeld, D.L., 1983. Louisiana coastal erosion program. In: Proceedings of the Northern Gulf of Mexico Estuaries and Barrier Islands Research Conference, 13-14 June 1983, Biloxi, $M S$, S.V. Shabica, N.B. Cofer and E.W.Cake, Jr. (Eds.). U.S. National Park Service, Southeast regional Office, Atlanta, GA, USA. 129-138.

Space Science and Engineering Center, 2002. Mississippi Delta. 08 January 2002 Terra Modis composite satellite image. Space Science and Engineering Center, University of WisconsinMadison, Madison, Wisconsin, USA. Website: http:// eosdb.ssec.wisc.edu/modisdirect/historical// (Accessed 11 August 2005).

Sparks, R.E., Bayley, P.B., Kohler, S.L. and Osborne, L.L., 1990. Disturbance and recovery of large floodplain rivers. Environ. Manage., 15, 699-709.

Stanton, T.P. and Ostrovsky, L.A., 1998. Observations of highly nonlinear internal solitons over the continental shelf. Geophys. Res. Lett., 25, 2695-2698.

Stone, G, W., Xu, J.P. and Zhang, X., 1995. Estimation of the wave field during Hurricane Andrew and morphological change along the Louisiana coast. J. Coastal Res. Special Issue 21, 234-253.

Stone, G.W., Grymes, J.M., III, Dingler, J.R. and Pepper, D.A., 1997. Overview and significance of hurricanes on the Louisiana coast, U.S.A. J. Coastal Res., 13, 656-669.

Stone, G.W., Grymes, J.M., III, Robbins, K.D., Underwood, S.G., Steyer, G.D. and Muller, R.A., 1993. A chronological overview of climatological and hydrological aspects associated with Hurricane Andrew and its morphological effects along the Louisiana coast, U.S.A. Shore Beach 61(2), 2-13.

Stora, G. and Arnoux, A., 1983. Effects of large freshwater diversions on benthos of a Mediterranean lagoon. Estuaries, 6, $115-125$.

Stuart, C.J. and Caughey, C.A., 1976. Form and composition of the Mississippi Fan. Gulf Coast Ass. Geol. Soc. Trans., 26, 333343

Sturges, W., 1993. The annual cycle of the western boundary current in the Gulf of Mexico. J. Geophys. Res., 98, 1805318068.

Sturges, W. and Blaha, J.P., 1976. A western boundary current in the Gulf of Mexico. Science, 192, 367-369.

Sturges, W. and Leben, R., 2000. Frequency of ring separations from the Loop Current in the Gulf of Mexico: A revised estimate. J. Phys. Oceanogr., 30, 1814-1819.

Sutula, M., Bianchi, T.S. and McKee, B.A., 2004. Effect of seasonal sediment storage in the lower Mississippi River on the flux of reactive particulate phosphorus to the Gulf of Mexico. Limnol. Oceanogr., 49, 2223-2235.

Swarzenski, P., 2001. Evaluating basin/shelf effects in the delivery of sediment-hosted contaminates in the Atchafalaya and Mississippi River deltas - a new U.S. Geological Survey Coastal and Marine Project. USGS Open-File Report OFR 01-215. Gulf of Mexico Integrated Science, U.S. Geological Survey, St. Petersburg, Florida, USA. 4pp. Website: http://gulfsci.usgs.gov/ missriv/reports/index.html (Accessed 11 August 2005).

Swenson, E.M. and Swarzenski, C.M., 1995. Water levels and salinity in the Barataria-Terrebonne estuarine system. In: Status and trends of Hydrologic Modification, Reduction in Sediment Availability, and Habitat Loss/Modification in the BaratariaTerrebonne Estuarine System, D.J. Reed (Ed.). BTNEP Pub. No. 20. Barataria-Terrebonne National Estuary Program, Thibodaux, LA, USA. 129-201.

Tanner, W.F., 1982. Hurricane effects. In: The Encyclopedia of Beaches and Coastal Environments, M.L. Schwartz (Ed.). Encyclopedia of Earth Sciences:Volume 15. Hutchinson Ross Publishing Co., Stroudsburg, PA, USA. 467.

Temple, R.F. and Martin, J.A., 1979. Surface Circulation in the Northwestern Gulf of Mexico as deduced from Drift Bottles. NOAA Technical Report NMFS SSRF - 730. U.S. Government Printing Office, Washington, DC, USA. 13pp.

Thomas, W.H. and Simmons, E.G., 1960. Phytoplankton production in the Mississippi Delta. In: Recent sediments, northwest Gulf of Mexico, F.P. Shepard, F.B. Phleger, and TH. van Andel (Eds.), American Association of Petroleum Geologists, Tulsa, Oklahoma, USA. 103-116 and 368-381.

Thompson, W.C., 1955. Sandless coastal terrain of the Atchafalaya Bay area, Louisiana. Spec. Publ. Soc. Econ. Paleontologists and Mineralogists No. 3, 52-76.

Toner, M., Kirwan, A.D., Jr., Poje, A.C., Kantha, L.H., MullerKarger, F.E. and Jones, C.K.R.T., 2003. Chlorophyll dispersal by eddy-eddy interactions in the Gulf of Mexico. J. Geophys. Res., 108(C4), 3105, doi:10.1029/2002JC001499.

Trefry, J.H., Metz, S., Nelsen, T.A., Trocine, R.P. and Eadie, B.J., 1994. Transport of particulate organic-carbon by the Mississippi River and its fate in the Gulf-of-Mexico. Estuaries, 17, 839849.

Turner, R.E. and Rabalais N.N., 1991. Changes in Mississippi River water quality this century. BioScience, 41, 140-147.

Turner, R.E. and Rabalais N.N., 1994. Coastal eutrophication near the Mississippi River delta. Nature, 368, 619-621.

Turner, R.E. and Rabalais N.N., 2003. Linking landscape and water quality in the Mississippi River basin for 200 years. BioScience, 53, 563-572.

Tyson, R.V. and Pearson, T.H. (Eds.), 1991. Modern and Ancient Continental Shelf Anoxia. Geological Society Special Publication No. 58. The Geological Society, London, UK. 470pp.

Uda, M., 1938. Researches on "siome" or current rip in the seas and oceans. Geophys. Mag., 11, 307-372.

US Army Corps of Engineers, 1974. Deep draft access to the ports of New Orleans and Baton Rouge. Draft Environmental Statement. US Army Corps of Engineers, New Orleans District, New Orleans, Louisiana, USA. As referenced by Dinnell and Wiseman, 1986 and Rabalais et al., 1999.

US Army Corps of Engineers (USCOE), 2004. Louisiana Coastal Area (LCA), Louisiana Ecosystem Restoration Study. Volume 1: LCA Study - Main Report. Draft. U.S. Army Corps of Engineers - New Orleans District. New Orleans, LA, USA. 230 pp. + attachments.

US Coast Service, 1861. Preliminary chart of the northwestern part of the Gulf of Mexico. Unfinished proof. US Coast Survey, Washington, DC, USA. Website: http://hdl.loc.gov/loc.gmd/ g9112m.cw0017800 (Accessed 02 November 2005). 
US Coast Service, 1863. Gulf coast of the United States; Key West to Rio Grande. US Coast Survey, Washington, DC, USA. Website: http://hdl.loc.gov/loc.gmd/g3862c.cw0047600 (Accessed 02 November 2005).

US Environmental Protection Agency (USEPA), 2004. Evaluation of the Role of Nitrogen and Phosphrous in Causing or Contributing to Hypoxia in the Northern Gulf. U.S. Environmental Protection Agency Region 4, 61 Forsyth Street SW, Atlanta, GA, USA. $21 \mathrm{pp}$. Website: www.initrogen.org/ fileadmin/user_upload/epa_august04_hypoxia_report.pdf (Accessed 21 March 2006).

US Geological Survey (USGS), 2003. 100+ years of land change for southeast coastal Louisiana (map). USGS-NWRC 2003-020373. USGS National Wetland Research Center, Lafayette, LA, USA.

U.S. Geological Survey (USGS), 2004. The Gulf of Mexico Hypoxic Zone. 2pp. Website: http://toxics.usgs.gov/hypoxia/ hypoxic zone (Accessed 09 December 2004).

Van Andē, T.H. and Poole, D.M., 1960. Sources of recent sediments in the northern Gulf of Mexico. J. Sed. Petrol., 30, $91-122$.

Van der Zwaan, G.J., 2000. Variation in natural vs. anthropogenic eutrophication of shelf areas in front of major rivers. In: Environmental Micropaleontology: The Application of Microfossils to Environmental Geology, R.E. Martin (Ed.) Kluwer Academic/Plenum Publishers, New York, NY, USA. 385-404.

Van Heerden, I. LI, Wells, J.T. and Roberts, H.H., 1981. Evolution and morphology of sedimentary environments, Atchafalaya delta, Louisiana. Trans. Gulf Coast Assoc. Geol. Soc., 31, 409416.

Van Sickle, V.R., Barrett, B.B., Ford, T.B. and Gulick, L.J., 1976. Barataria Basin: Salinity Changes and Oyster Distribution. Louisiana State University Sea Grant Publication No. LSU-T76-02. Louisiana State University, Baton Rouge, LA, USA. $22 \mathrm{pp}$.

Vidal, V.M.V., Vidal, F.V., Meza, E., Portilla, J., Zambrano, L. and Jaimes, B., 1999. Ring-slope interactions and the formation of the western boundary current in the Gulf of Mexico. $J$. Geophys. Res., 104, 20,523-20,550.

Wahby, S.D. and Bishara, N.F., 1982. The effect of the River Nile on Mediterranean water, before and after the construction of the High Dam at Aswan River. In: Inputs to Ocean Systems, J.M. Martin, J.D. Burton and D. Eisma (Eds.). United Nations, New York, NY, USA. 311-317.

Wakesman, S.A. and M. Hotchkiss, M., 1937. On the oxidation of organic matter in marine sediments by bacteria. J. Mar. Res., $1,101-118$.

Walsh, J.J., 1991. Importance of continental margins in the marine biogeochemical cycling of carbon and nitrogen. Nature, $\mathbf{3 5 0}$, 53-55.

Walsh, J.J., Dieterle, D.A., Meyers, M.B. and Muller-Karger, F.E., 1989. Nitrogen exchange at the continental Margin: A numerical study of the Gulf of Mexico. Prog. Oceanogr., 23, 245-301.

Wang, W., Nowlin, W.D., Jr. and Reid, R.O., 1998. Analyzed surface meteorological fields over the northwestern Gulf of Mexico for 1992-1994: mean, seasonal, and monthly patterns. Mon. Weather Rev., 126, 2864-2883.

Wawrik, B., Paul, J.H., Campbell, L., Griffin, D., Houchin, L., Fuentes-Ortega, A. and Muller-Karger, F., 2003. Vertical structure of the phytoplankton community associated with the coastal plume in the Gulf of Mexico. Mar. Ecol. Prog. Ser., 251, 87-101.

Wawrik, B. and Paul, J.H., 2004. Phytoplankton community structure and productivity along the axis of the Mississippi River plume in oligotrophic Gulf of Mexico waters. Aquat. Microb. Ecol., 35, 185-196.
Wawrik, B., Paul, J.H., Bronk, D.A. and Gray, J.D., 2004. High rates of ammonium recycling drive phytoplankton productivity in the offshore Mississippi River plume. Aquat. Microb. Ecol., 35, 175-184.

Weatherly, G., Wienders, N. and Harkema, R., 2003. Temperature inversions in the open Gulf of Mexico. J. Geophys. Res., 108, 3177, doi1029/2002JC001680.

Wells, J.T., 1980. Fluid mud dynamics and shoreline stabilization. In: 17th International Conference on Coastal Engineeringex:, 23-28 March 1980, Sydney, A.C.T. Barton (Ed.). Institute of Engineers, Australia. 101-102.

Wells, J.T. and Kemp, G.P., 1981. Atchafalaya mud stream and recent mudflat progradation: Louisiana Chenier Plain. Trans. Gulf Coast Assoc. Geol. Soc., 31, 409-416.

Wells, J.T. and Kemp, G.P., 1982. Mudflat and marsh progradation along Louisiana's chenier plain: a natural reversal of coastal erosion. In: Proceedings of the Conference on Coastal Erosion and Wetland Modification in Louisiana: Causes, Consequences, and Options, D.F. Boesch (Ed.). U.S. Fish and Wildlife Service, Washington, DC, USA. 39-51.

Wells, J.T. and Coleman, J.M., 1987. Wetland loss and the subdelta life cycle. Estuar. Coast. Shelf Sci., 25, 111-125.

Welsh, S.E. and Inoue, M., 2002. Langrangian study of circulation, transport, and vertical exchange in the Gulf of Mexico: final report. OCS Study MMS 2002-064. U.S. Dept. of the Interior, Minerals Management Service, Gulf of Mexico OCS Region, New Orleans, LA, USA. 51pp.

Wenger, L.M. and Baker, D.R., 1986. Variations in organic geochemistry of anoxic-oxic black shale-carbonate sequences in the Pennsylvanian of the Midcontinent, U.S.A. Org. Geochem., 10, 85-92.

Wenger, L.M., Baker, D.R., Chung, H.M. and McCulloh, T.H., 1988. Environmental control of carbon isotope variations in Pennsylvanian black-shale sequences, Midcontinent, U.S.A. Org. Geochem., 13, 765-771.

Wennekens, M.P., 1959. Water mass properties of the Straits of Florida and related waters. Bull. Mar. Sci. Gulf Carib., 9, 1-52.

Wetzel, R.G., 1979. The role of the littoral zone and detritus in lake metabolism. Arch. Hydrobiol. Beih. Ergebn. Limnol., 13, $145-161$.

Wetzel, R.G. 1983. Limnology. Second Edition. Saunders College Publishing, Philadelphia, USA. 767pp.

White, D.A., Weiss, T.E., Trapani, J.M. and Thien, L.B., 1978 Productivity and decomposition of the dominant salt marsh plants in Louisiana. Ecology, 59, 751-759.

Wignall, P.B. and Newton, R., 2001. Black shales on the basin margin: a model based on examples from the Upper Jurassic of the Boulonnais, northern France. Sed. Geol., 144, 335-356.

Wiseman, W.J., Jr. and Sturges, W., 1998. Physical oceanography of the Gulf of Mexico: Process that regulate its biology. In: The Gulf of Mexico large marine ecosystem, H. Kumpf, K. A. Steidinger and K. Sherman (Eds.), Blackwell Science, Inc., Malden, Massachusetts, USA. 77-92.

Woodring, H.H., 1936. Beach erosion at Grand Isle, LA. In: Document No. 92, House of Representatives, $75^{\text {th }}$ Congress, $1 \mathrm{st}$ Session. $31 \mathrm{pp}$.

Wright, L.D., 1977. Sediment transport and deposition at river mouths: a synthesis. Geol. Soc. Amer. Bull., 88, 857-868.

Wright, L.D. and Coleman, J.M., 1973. Variations in morphology of major river deltas as functions of ocean wave and river discharge regimes. Amer. Assoc. Petrol. Geol. Bull., 57, 370398.

Yang, Z.S., Milliman, J.D., Galler, J., Liu, J.P. and Sun, X.G., 1998. Yellow River's water and sediment discharge decreasing steadily. EOS, Trans. Amer. Geophys. Union, 79, 589,592. 
Zangerl, R. and Richardson, E.S., Jr., 1963. The Paleoecological History of Two Pennsylvanian Black Shales. Fieldiana: Geology Memoirs Vol. 4. Chicago Natural History Museum, Chicago, IL, USA. 352pp.

Zavala-Hidalgo, J., Morey, S.L. and O'Brien, J.J., 2003. Seasonal circulation on the western shelf of the Gulf of Mexico using a high-resolution numerical model. J. Geophys. Res., 108(C12), 3389, doi:10.1029/2003JC001879.

\section{Appendix}

Figure 1 The spectrum of sea surface temperatures ranging from red through green illustrates the flow of the Gulf of Mexico's Boundary Current and its Loop Current on 23 February 2003. Fluid lines defining coloured areas depict regimes of sea surface temperatures of the Gulf of Mexico. Sharp, speckled and streaked coloured (temperature) features and areas of white are clouds. The area of deepest red represents warm Caribbean seawater passing into and through the Gulf with the Loop Current. The Boundary Current along the margins of the Gulf is highlighted by cold upwelled water flanked inshore and offshore by warmer waters. The westward flow of Mississippi River water stops and then falls back on itself much as a fountain does in trying to overcome the downward pull of gravity. In this case, the force operating against the Mississippi's westward outflow is the eastward motion of the Gulf's Boundary Current. The eastward flow of cold water out of the third bay to the west of the Mississippi is the outflow from the Atchafalaya River (see Fig. 2 for greater detail). The Louisiana Coastal Current is a nearshore current too small to generate features comprehensively discernable at the scale of this figure. The Coastal Current's direction of flow is reversible and sensitive to prevailing wind direction.

Additional supporting satellite imagery for this day can be accessed through the Space Science and Engineering Center website: http://eosdb.ssec.wisc.edu/modisdirect/ historical/. Higher resolution sea surface temperature and turbidity satellite images of the Mississippi River Delta and the area of the Atchafalaya River for this day can be accessed on the Louisiana State University's Earth Scan Laboratory website: http://www.esl.1su.edu/research/NOAA_AVHRR/ archive_baywatch.php?day

Chlorophyll images for this day are available from the NASA website: http://oceancolor.gsfc.nasa.gov/cgi/level3.pl

A complilation of related images is posted by the Illinois State Water Survey (Krug and Merrifield, 2007).

Figure 2 The distribution of green, yellow, brown and blue colours is informative of what is happening in this 22 May 2002 view of the northern Gulf of Mexico. White is cloud. Deep blue is indicative of clear Gulf water; blues with milky casts are consistent with the presence of coccolith algae (whose carbonate shells make chalk). The strong eastward movement of the Gulf's Boundary Current across the bottom of this picture is better viewed during the cool months (e.g. Krug, 2007; Krug and Merrifield, 2006). The Boundary Current interacts dynamically with shelf water, Atchafalaya River water and Mississippi River water, and the waters of various estuaries - as indicated by the distribution of yellow and brown sediment-laden water and green algae water. Much water from the Atchafalaya River and its nearby shelf area is moved offshore and east to over the Mississippi Trough where it is blocked from further eastward movement by the inflow of Gulf water. The same happens to water issuing from the Mississippi River's southwest outlet and the offshore outflows of the organic-rich brown waters of the Terrebonne and Barataria estuaries at the head of the Mississippi Trough. The Atchafalaya empties into a bay from whose westernmost part the yellowish muddy Louisiana Coastal Current flows westward toward Texas. Water offshore of this coastal current is generally moving eastward in concert with the Boundary Current.

Additional supporting satellite imagery is available as documented for Fig. 1.

Kathy Brown is thanked for making both images. 